\title{
GIS and Multicriteria Decision Analysis for Landfill Site Selection in Al-Hashimyah Qadaa
}

\author{
Mohammad Ali Alanbari' ${ }^{1}$ Nadhir Al-Ansari ${ }^{*}$, Hadeel Kareem Jasim ${ }^{1}$ \\ ${ }^{1}$ University of Babylon, Babylon, Iraq \\ ${ }^{2}$ Lulea University of Technology, Lulea, Sweden \\ Email: Profdr alanbari@yahoo.com, nadhir.alansari@ltu.se, hadeel.k_alrubaiey@yahoo.com
}

Received 31 December 2013; revised 31 January 2014; accepted 7 February 2014

Copyright (C 2014 by authors and Scientific Research Publishing Inc.

This work is licensed under the Creative Commons Attribution International License (CC BY). http://creativecommons.org/licenses/by/4.0/

(c) () Op Open Access

\begin{abstract}
Waste management system is not well regulated in Iraq. Despite the fact that there are various techniques used for solid waste disposal, landfill is the most common mode for the disposal of solid waste in Iraq, landfill site selection criteria is quite complex process and it depends on several regulation and factors. In this study landfill site selection is performed by using Multicriteria Decision Analysis (MCDA) and Geographic Information System (GIS) for the Al-Hashimyahqadaa. Existing landfills in qadaa are temporary and/or non-conforming to the environmental conditions. In order to determine landfill site, several criteria were examined such as urban centers, land use, airports, pipes, power lines, railways, roads, slope, streams, surface water, industrial areas, oil pipes, liquid gas pipes, soil types are prepared. MCDA was used to measure the relative importance weighting for each criterion. Each map layer was prepared using GIS and the final suitable map was created by overlay analyses of each criterion map. According to the results, high and low suitable areas were determined in the study area. Field site check was performed to determine the accuracy and suitability of the candidate sites.
\end{abstract}

\section{Keywords}

GIS; Multicriteria Decision Analysis; Landfill; Site Selection Criteria

\section{Introduction}

Waste problem all over the world is of growing concern especially in developing countries [1] [2]. Source re-

*Corresponding author. 
duction, recycling and waste transformation are methods widely used to manage solid waste, however, in all these methods there is always a residual matter even after the recovery process for disposal. The necessity of getting rid of these waste yields in an economical way is referred to as landfilling [3]. Landfill siting is an extremely difficult task to accomplish because the site selection process depends on different factors and regulations. It is becoming increasingly difficult due to growing environmental awareness, the decreased amount of governmental and municipal funding with extreme political and social opposition. The increasing population densities, public health concerns, and less land available for landfill construction are also the difficulties to overcome [4]. For this reason there are no international code that could be applied due to the variation of the factors involved in the site concerned [5] [6].

Environmental factors are very important because the landfill may affect the biophysical environment and the ecology of the surrounding area [7]. Several techniques can be found for site selection criteria for solid waste disposal in [1] [5] [6] [8]-[23]. Such siting techniques combine multiple criteria analysis (MCDA) and GIS [4] [7] [24]-[27]. The result of these techniques is the evaluation of the suitability for the entire concerned site based on a suitability index, which is useful in order to make an initial ranking of the most suitable areas.

Candidate sites for an appropriate landfill area in the vicinity of Ankara were determined using the integration of Geographic Information Systems and Multicriteria Decision Analysis. For this purpose, sixteen input map layers were prepared [28]. A research conducted by Din [29] aimed to develop a landfill siting methodology employing GIS, and a multi-criteria decision making (MCDM) rule, consisting of analytical hierarchy processes (AHP) and weighted linear combinations (WLC). The proposed method was applied to the study area of the District of Klang, Selangor, Malaysia.

GIS has matured into a powerful tool that can integrate driven types of spatial data and perform a variety of spatial analysis. This evolution had been driven by significant advances in computer technology and the availability and quantity of data.

GIS and environmental models function with a board spectrum of geospatial data that are used for divers' applications and spatial analyses at different scales. The examination and organization of data into a useful form produces information, which then enables appropriate analysis and modeling.

The objective of this study is to select sites for an appropriate landfill area of Al-Hashimyahqadaa in Babylon governorate using the integration of Geographic Information Systems (GIS) and Multicriteria Decision Analysis (MCDA). In addition, the required landfill area to cover generated Municipal Solid Waste (MSW) volume for at least five years was calculated. Using these approaches, will lead to integrated environmental management, that are necessary to allow consideration of all components and processes in environment; their spatial, temporal, and human dimensions; their interaction and correlation, coupled with social, economic, political, and legal impacts. Consequently, 14 input digital map layers including urban centers, land use, airports, pipes, power lines, railways, roads, slope, streams, surface water, industrial areas, oil pipes, liquid gas pipes, soil types are prepared and multi-criteria analyses are implemented with a geographical information system.

\section{Methodology}

\subsection{Study Area}

Al-Hashimyahqadaa is located to the south of Babylon governorate in Iraq, in the city of Al-Hashimyah center (Figure 1), with a population of about 414,644 according to the files of the Directorate of Environmental Affairs in Babel (DEAB) [30]. It lies approximately between latitudes $32^{\circ} 6^{\prime}, 32^{\circ} 31^{\prime} \mathrm{N}$, and longitudes $44^{\circ} 29^{\prime}, 45^{\circ} 12^{\prime} \mathrm{E}$ longitude, the total area of the Al-Hashimyahqadaa is $1646 \mathrm{~km}^{2}$, and Population growth rate is $3.3 \%$ [30].

\subsection{Methodology}

Identification of evaluation Criteria required for landfill siting selection in Al-Hashimyah qadaa were identified and evaluated. All these criteria had been identified based on the local guidelines of Town and Country Planning Department (TCPD), waste disposal siting and the Department of Environment (DOE). In addition, the related information about landfill siting was also reviewed from the international perspective, such as the Environmental Protection Agency (EPA) [31]. All the data pertaining to these parameters were taken from the relevant agencies, however, not all parameters were included due to the lack of data availability. In this study, integration of GIS and (MCDA) was used and applied to Al-Hashimyah qadaa. To achieve this goal, 14 criteria were identi- 


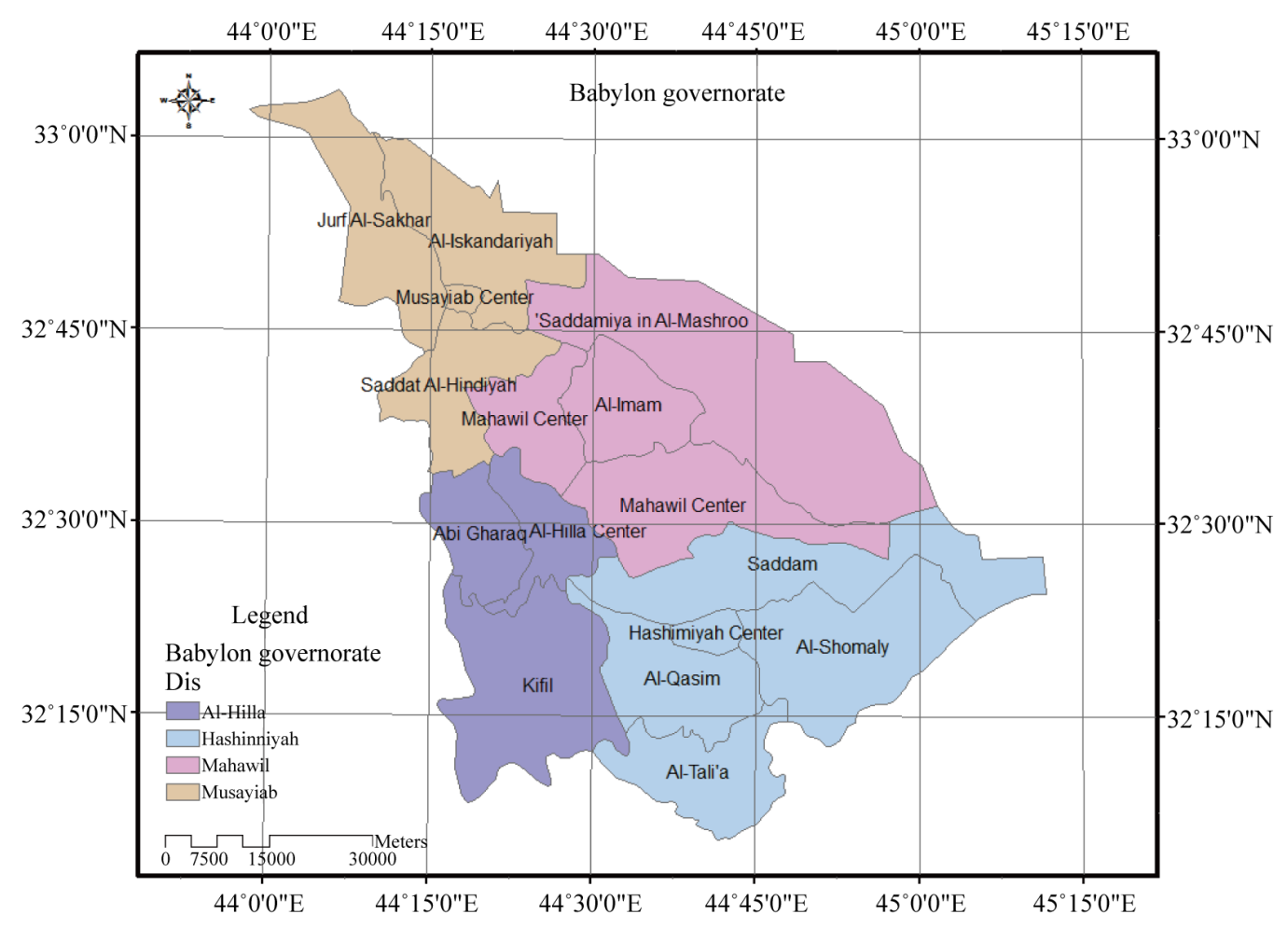

Figure 1. The map of Babylon governorate (source of data from [30]).

fied for landfill site selection, they were urban centers, land use, airports, pipes, power lines, railways, roads, slope, streams, surface water, industrial areas, oil pipes, liquid gas pipes and soil types. ArcGIS9.3 software was used for imaging and analysis of spatial data. Additionally, several GIS analyses such as buffer zoning, distance, reclassify and overlay analysis were also used. In order to evaluate the site selection criterion, MCDA was used to measure the relative importance weights for the parameters used. This is due to the fact that, MCDA divides the decision problems into smaller understandable parts, and analyzes each part separately, and then integrates these parts in a logical manner [32].

\subsection{Population Growth Rate}

Population growth rate $(r)$ was calculated based on estimates of population size of the Babylon governorate, for the period (2004-2010) was obtained from Babylon environmental directorate [30] using the following equation [33]:

$$
P_{2010}=P_{2004}(1+r)^{n}
$$

where:

$n=$ number of years, $P$ = population.

Using the above population growth rate equation, Al-Hashimyahqadaa in Babylon governorate, population was calculated for individual years from 2011 to 2017. The overall average growth rate for Al-Hashimyah district was $3.3 \%[30]$.

\subsection{Municipal Solid Waste Volume (MSW) for Site Area Requirement}

One of the important criteria in selecting landfill site is site area requirement. For this Purposes, the volume of Municipal Solid Waste (MSW) to be disposed in this site should be estimated. The link between the populations of Al-Hashimyahqadaa, for the years 2004, 2005, 2006, 2007, 2008, 2009, 2010 and the amount of solid waste generated for the same years in Al-Hashimyah qadaa was achieved using the following relationships (Figure 2):

$$
y=148526.09 \ln (x)-1862974.48
$$




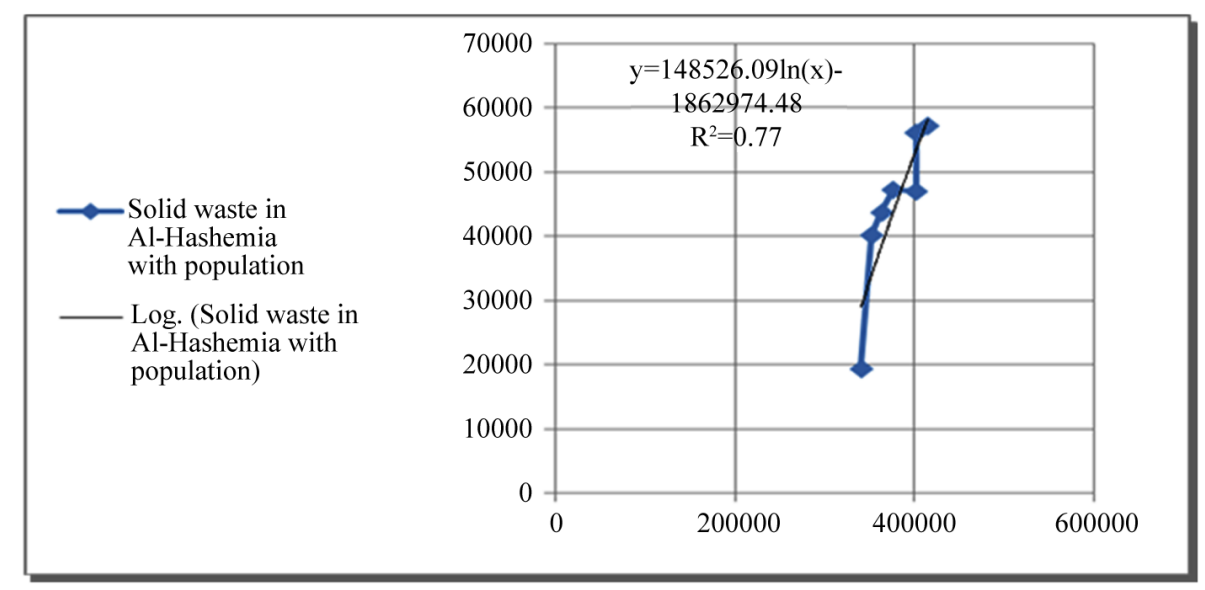

Figure 2. Solid waste (y-axis) in the center of Babylon governorate (Al-Hashimyah qadaa) with its population (X-axis) (source of data from [30]).

where:

$$
R^{2}=0.77
$$

$X$ : Population in Al-Hashimyah, $Y$ : Solid waste for the same year.

The sum of the solid waste in five years for Al-Hashimyahqadaa is illustrated in Table 1. The expected weight and volume of solid waste for the period 2013-2017 reached 411738 tons and 914973 cubic meters respectively. It should be mentioned however, that the volume was calculated assuming compacting density of Iraqi municipal solid waste as $0.45 \mathrm{t} / \mathrm{m}^{3}$ [34].

\subsection{Criteria Analysis}

The decision tree developed for the landfill site selection problem in Al-Hashimyah qadaa is shown in Figure 3, where 14 criteria were prepared as input digital map layers including urban centers, land use, airports, pipes, power lines, railways, roads, slope, streams, surface water, industrial areas, oil pipes, liquid gas pipes, and soil types.

\subsubsection{Criteria Weights}

Criteria weight can be defined as a value assigned to an evaluation criterion which indicates its importance relative to other criterias under consideration. Assigning weights of importance for the evaluation criteria accounts for 1) the changes in the range of variation for each evaluation criterion, and 2) the different degrees of importance being attached to these ranges of variation [35]. There are four different techniques when assigning the weights: ranking, rating, pairwise comparison and trade of analysis methods. Calculating weight for the criteria using the method of pairwise comparison method has advantages. The advantages is that two criteria had to be considered at a time, it can be implemented in a spreadsheet environment [35] and it is incorporated into GIS based decision making procedures [36]. The weights of criteria had been computed using comparison matrix as shown in Figure 4 by using scale values of 1 - 9 (Table 2) [37]. The comparison matrix indicating the relative importance of the criterion in the columns compared to the criterion in the rows are shown in Table 3 [28]. For each comparison it was decided which of the two criteria was most important, and then assigned score was given to show how much more important it is.

Test of consistency: The aim of this is to determine if the comparisons are consistent or not. It involves following operations:

a) Determine the weighted sum vector by multiplying the weight for the first criterion times the first column of the original pairwise comparison matrix, then multiply the second weight times the second column, the third criterion times the third column of the original matrix, finally sum these values over the rows,

b) Determine the consistency vector by dividing the weighted sum vector by the criterion weights determined previously,

c) Compute lambda $(\lambda)$ which is the average value of the consistency vector and consistency index (CI) which 
Table 1. Solid waste in Al-Hashimyah qadaa with its population [30].

\begin{tabular}{ccc}
\hline Year & $\begin{array}{c}\text { Al-Hashemiaqadaa } \\
\text { Population }\end{array}$ & Solid waste (ton) \\
\hline 2004 & 340,653 & 19,345 \\
2005 & 351,894 & 40,150 \\
2006 & 363,507 & 43,679 \\
2007 & 375,947 & 47,208 \\
2008 & 401,773 & 46,967 \\
2009 & 401,773 & 56,102 \\
2010 & 414,644 & 57,172 \\
2011 & 428,327 & 63,058 \\
2012 & 442,462 & 67,881 \\
2013 & 457,063 & 72,703 \\
2014 & 472,146 & 77,525 \\
2015 & 487,727 & 82,348 \\
2016 & 503,822 & 87,170 \\
2017 & 520,448 & 91,992 \\
\hline
\end{tabular}

Table 2. Scale for pairwise comparison [37].

\begin{tabular}{cc}
\hline Intensity of importance & Definition \\
\hline 1 & Equal importance \\
3 & Equal to moderately importance \\
4 & Moderate importance \\
5 & Moderate to strong importance \\
6 & Strong importance \\
7 & Strong to very strong importance \\
8 & Very strong importance \\
9 & Very to extremely strong importance \\
\end{tabular}

Table 3. Comparison matrix.

\begin{tabular}{ccccccccccccccc}
\hline & $\mathrm{Ur}$ & $\mathrm{Lu}$ & $\mathrm{Ai}$ & $\mathrm{Pi}$ & $\mathrm{Pl}$ & $\mathrm{Ra}$ & $\mathrm{Ro}$ & $\mathrm{Sl}$ & $\mathrm{St}$ & $\mathrm{Sw}$ & $\mathrm{In}$ & $\mathrm{Oi}$ & $\mathrm{Lg}$ & $\mathrm{St}$ \\
\hline $\mathrm{Ur}$ & 1 & 5 & 7 & 5 & 7 & 9 & 7 & 5 & 3 & 3 & 5 & 5 & 5 & 4 \\
$\mathrm{Lu}$ & $1 / 5$ & 1 & 3 & 2 & 3 & 4 & 3 & 2 & $1 / 3$ & $1 / 3$ & 1 & 2 & 2 & $1 / 2$ \\
$\mathrm{Ai}$ & $1 / 7$ & $1 / 3$ & 1 & $1 / 2$ & 1 & 2 & 1 & $1 / 2$ & $1 / 5$ & $1 / 5$ & $1 / 3$ & $1 / 2$ & $1 / 2$ & $1 / 4$ \\
$\mathrm{Pi}$ & $1 / 5$ & $1 / 2$ & 2 & 1 & 2 & 3 & 2 & 1 & $1 / 4$ & $1 / 4$ & $1 / 2$ & 1 & 1 & $1 / 3$ \\
$\mathrm{Pl}$ & $1 / 7$ & $1 / 3$ & 1 & $1 / 2$ & 1 & 2 & 1 & $1 / 2$ & $1 / 5$ & $1 / 5$ & $1 / 3$ & $1 / 2$ & $1 / 2$ & $1 / 4$ \\
$\mathrm{Ra}$ & $1 / 9$ & $1 / 4$ & $1 / 2$ & $1 / 3$ & $1 / 2$ & 1 & $1 / 2$ & $1 / 3$ & $1 / 7$ & $1 / 7$ & $1 / 4$ & $1 / 3$ & $1 / 3$ & $1 / 5$ \\
$\mathrm{Ro}$ & $1 / 7$ & $1 / 3$ & 1 & $1 / 2$ & 1 & 2 & 1 & $1 / 2$ & $1 / 5$ & $1 / 5$ & $1 / 3$ & $1 / 2$ & $1 / 2$ & $1 / 4$ \\
$\mathrm{Sl}$ & $1 / 5$ & $1 / 2$ & 2 & 1 & 2 & 3 & 2 & 1 & $1 / 4$ & $1 / 4$ & $1 / 2$ & 1 & 1 & $1 / 3$ \\
$\mathrm{St}$ & $1 / 3$ & 3 & 5 & 4 & 5 & 7 & 5 & 4 & 1 & 1 & 3 & 4 & 4 & 2 \\
$\mathrm{Sw}$ & $1 / 3$ & 3 & 5 & 4 & 5 & 7 & 5 & 4 & 1 & 1 & 3 & 4 & 4 & 2 \\
$\mathrm{In}$ & $1 / 5$ & 1 & 3 & 2 & 3 & 4 & 3 & 2 & $1 / 3$ & $1 / 3$ & 1 & 2 & 2 & $1 / 2$ \\
$\mathrm{Oi}$ & $1 / 5$ & $1 / 2$ & 2 & 1 & 2 & 3 & 2 & 1 & $1 / 4$ & $1 / 4$ & $1 / 2$ & 1 & 1 & $1 / 3$ \\
$\mathrm{Lg}$ & $1 / 5$ & $1 / 2$ & 2 & 1 & 2 & 3 & 2 & 1 & $1 / 4$ & $1 / 4$ & $1 / 2$ & 1 & 1 & $1 / 3$ \\
$\mathrm{St}$ & $1 / 4$ & 2 & 4 & 3 & 4 & 5 & 4 & 3 & $1 / 2$ & $1 / 2$ & 2 & 3 & 3 & 1 \\
\hline
\end{tabular}

"Ur: Urban centers, Lu: Land use, Ai: Airports, Pi: Pipes, Pl: Power lines, Ra: Railways, Ro: Roads, Sl: slope, St: streams, Sw: Surface water, In: Industrial areas, Oi: Oil pipes, Lg: Liquid gas pipes, St: Soil types [28]. 


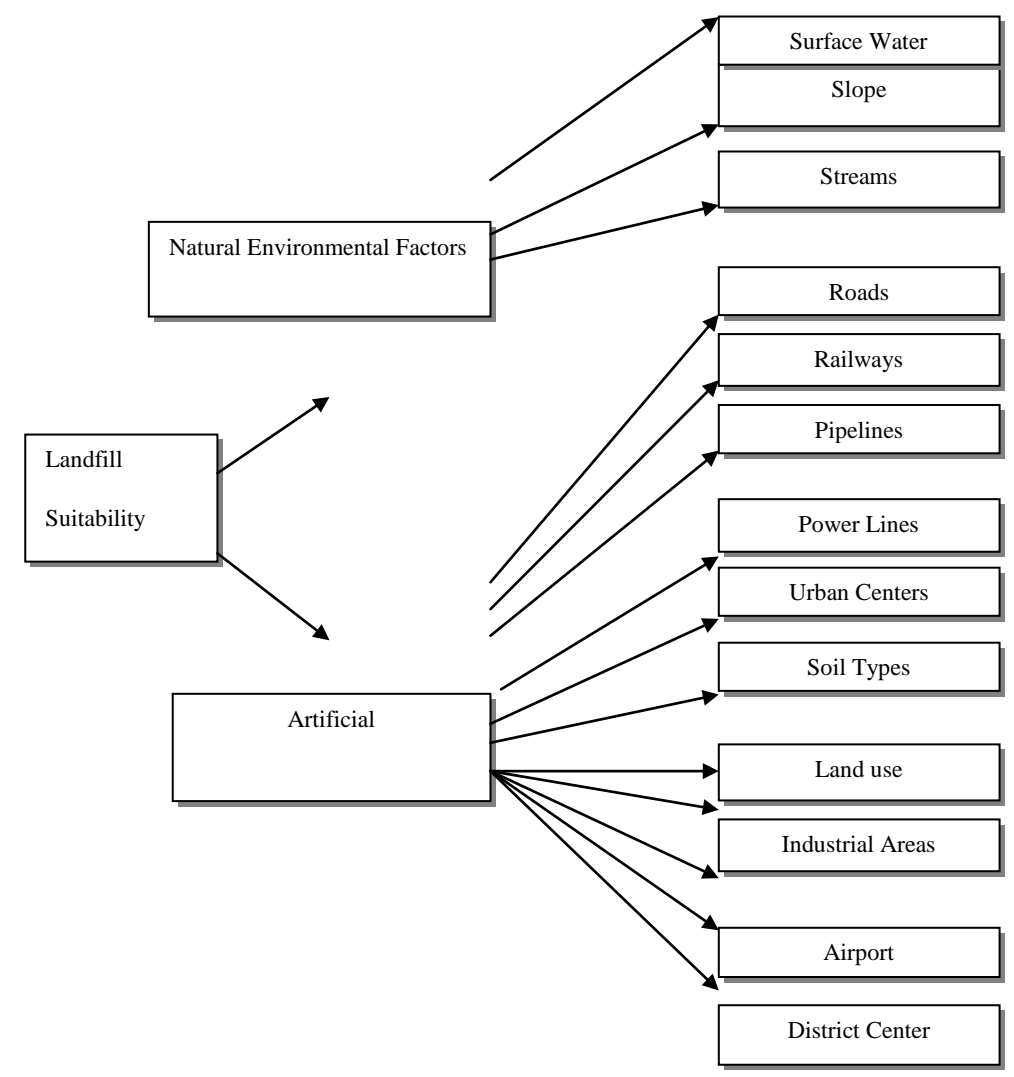

Required Area

Figure 3. The decision tree developed for the landfill site selection in AlHashimyah qadaa.

$44^{\circ} 25^{\prime} 0^{\prime \prime} \mathrm{E} 44^{\circ} 30^{\prime} 0^{\prime \prime} \mathrm{E} 44^{\circ} 35^{\prime} 0^{\prime \prime} \mathrm{E} 44^{\circ} 40^{\prime} 0^{\prime \prime} \mathrm{E} 44^{\circ} 45^{\prime} 0^{\prime \prime} \mathrm{E} 44^{\circ} 50^{\prime} 0^{\prime \prime} \mathrm{E} 44^{\circ} 55^{\prime} 0^{\prime \prime} \mathrm{E} 45^{\circ} 0^{\prime} 0^{\prime \prime} \mathrm{E} 45^{\circ} 5^{\prime} 0^{\prime \prime} \mathrm{E} 45^{\circ} 10^{\prime} 0^{\prime \prime} \mathrm{E}$

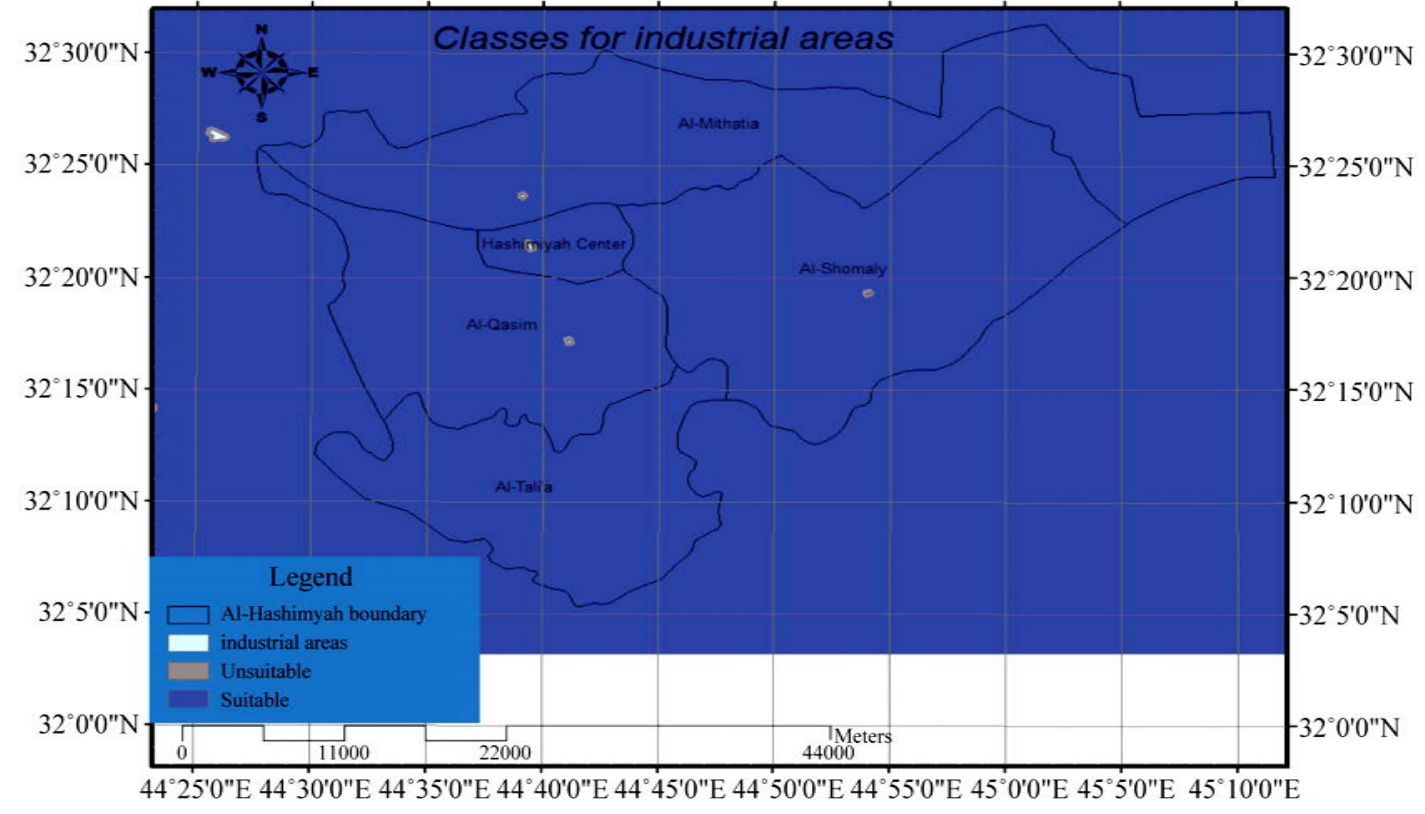

Figure 4. Classes for industrial areas (source of data from [43]). 
provides a measure of departure from consistency and has the formula below:

$$
\mathrm{CI}=(\lambda-n) /(n-1)
$$

d) Calculation of the consistency ratio (CR) which is defined as follows:

$$
\mathrm{CR}=\mathrm{CI} / \mathrm{RI}
$$

where RI is the random index and depends on the number of elements being compared.

If $\mathrm{CR}<0.10$, the ratio indicates a reasonable level of consistency in the pairwise comparison, however, if CR $\geq 0.10$, the values of the ratio indicates inconsistent judgments.

$\lambda \max =14.327, \mathrm{CI}=0.025, \mathrm{RI}=1.57$ and $\mathrm{CR}=0.016<0.1$. See the resulting weights in Table 4 [38].

\subsubsection{Digital Environmental Maps}

It is evident that many factors must be incorporated into landfill siting decisions, and geographic information systems (GIS) due to its ability to manage large volumes of spatial data from a variety of sources. It efficiently stores, retrieves, analyzes and displays the information according to user-defined specifications [7]. Preparing analysis of digital environmental maps illustrated below.

\section{1) Settlement Areas}

Settlement areas were subdivided into two layers. First layer consists of residential areas; while the second layer was for industrial areas. The reason for this division was the necessity for applying different buffer zone distances to the residential and industrial areas. According to Allen, and et al. [26] [39] the distance from residential areas should be at least $5 \mathrm{~km}$ and from isolated houses $500 \mathrm{~m}$ to locate a landfill site. The buffer distances for towns and villages within a population greater than 500 people were determined as $1000 \mathrm{~m}$. As far as all other identified centers of population it was assumed to be $500 \mathrm{~m}$ and for private residences, businesses, social and community buildings as $250 \mathrm{~m}$ [40]. Siddiqui [7] suggested that no new landfill site should be located closer than $0.4 \mathrm{~km}$ from a collection of ten or more houses. On the other hand, the landfill site should be located within $10 \mathrm{~km}$ of an urban area due to economic considerations [41]. By considering all the suggested safe distances, minimum distances for the study area were determined as $5 \mathrm{~km}$ for residential areas and $250 \mathrm{~m}$ for industrial areas. These distances were used to create buffer zones around settlement areas and were excluded from the study area. After exclusion of absolutely unsuitable areas for landfill sites, the remainder areas were classified according to their suitability. The layer of industrial areas were classified as suitable or unsuitable by assigning values 1 and 0 respectively (Table 5 and Figure 4).

The layer for residential areas was divided into four classes. The classes and related ranks are given in Table 6. The residential areas layer as then prepared based on the ranking values shown in Table 6 and Figure 5.

\begin{tabular}{cc} 
Table 4. Resulting weights. & Weights \\
\hline Criteria & 0.265 \\
\hline Urban centers & 0.071 \\
Land use & 0.026 \\
Airports & 0.044 \\
Pipes & 0.026 \\
Power lines & 0.017 \\
Railways & 0.026 \\
Roads & 0.044 \\
Slope & 0.155 \\
Streams & 0.155 \\
Surface water & 0.071 \\
Industrial areas & 0.044 \\
Oil pipes & 0.044 \\
Liquid gas pipes & 0.097 \\
Soil types &
\end{tabular}


Table 5. Classes produced for the industrial areas of settlement criteria according to the suitability for landfill [42].

\begin{tabular}{cc}
\hline Ranking & Distance to industrial area \\
0 & $0 \mathrm{~m}-250 \mathrm{~m}$ \\
1 & $>250 \mathrm{~m}$ \\
\hline
\end{tabular}

Table 6. Classes produced for the residential areas of settlement criteria according to the suitability for landfill [42].

\begin{tabular}{cc}
\hline Distance to urban centers & Ranking \\
\hline $0 \mathrm{~m}-5000 \mathrm{~m}$ & 0 \\
$5000 \mathrm{~m}-10000 \mathrm{~m}$ & 10 \\
$10000 \mathrm{~m}-15000 \mathrm{~m}$ & 5 \\
$>15000 \mathrm{~m}$ & 1 \\
\hline
\end{tabular}

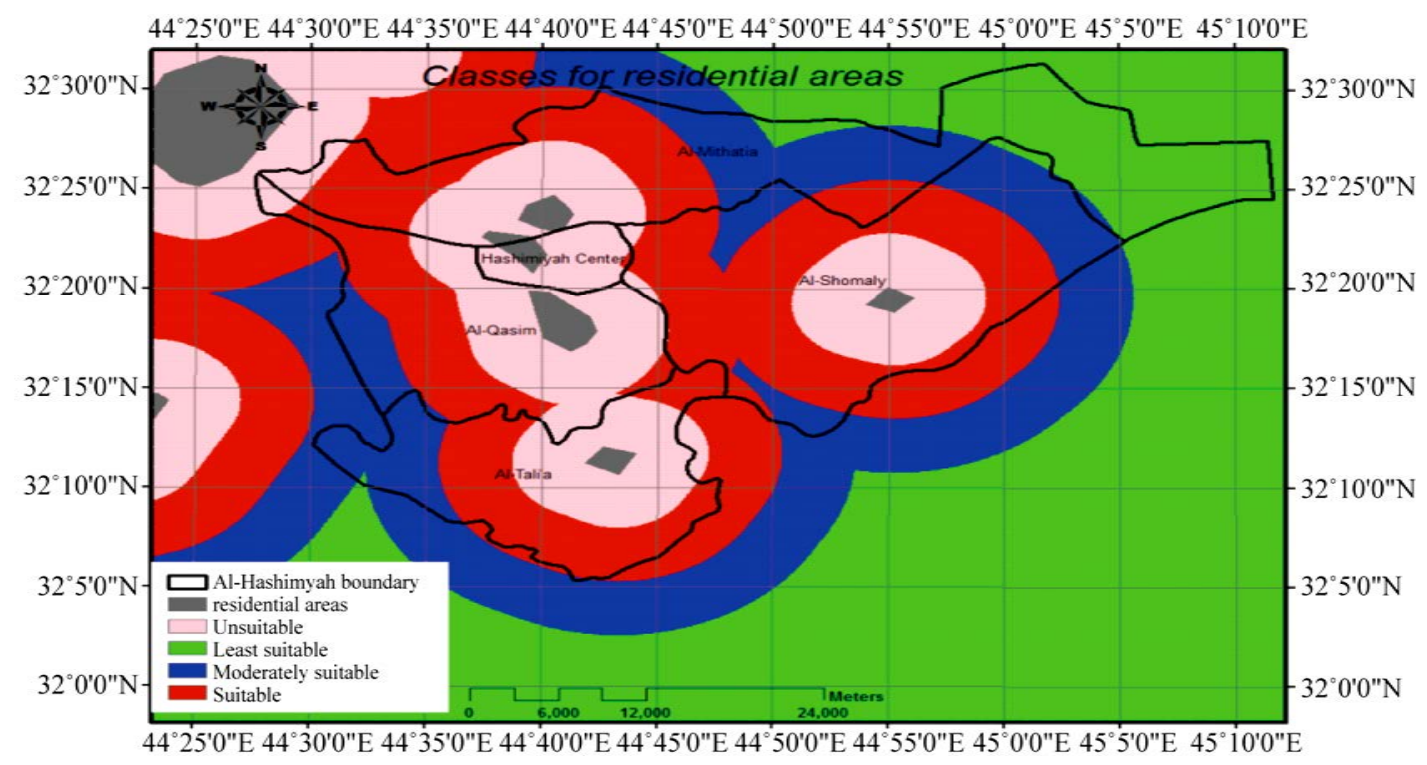

Figure 5. Classes for residential areas (source of data from [43]).

\section{2) Roads}

There are many suggested buffer zone distances. Minimum distance from the network is imported in order to avoid visual impact and other nuisances. Roads plus $100 \mathrm{~m}$ buffer areas from both sides should be applied [44]. According to Cantwell [40], all roads including primary, secondary, regional and third class roads should be avoided and have a buffer of at least $30 \mathrm{~m}$ on both sides. Allen [39] and Allen et al. [45] stated that a distance greater than $1 \mathrm{~km}$ from main roads and highways should be avoided. On the other hand, the landfill site should not be placed too far away from existing road networks to avoid the expensive cost of constructing connecting roads [25]. Distance from main access roads should be smaller than $3 \mathrm{~km}$ [39] [45] and between $0.2 \mathrm{~km}$ and 10 $\mathrm{km}$ of a major road [41]. By considering these suggested values, the buffer zones and related ranks were determined for roads which are shown in Table 7.

The values on the tables given above are entered to the database and each value was assigned to the related class. Finally, the vector maps were converted to raster maps as shown in Figure 6.

\section{3) Railways}

The necessary buffer zone distances and related rankings were directly used in Table 8 [41]. The buffer zones were created. The values on the table were loaded to the database and each value was assigned to the related class in the GIS environment. The layer of railways was classified as suitable or unsuitable by assigning values 1 
Table 7. Classes produced for the main roads of road criteria according to the suitability for landfill [42].

\begin{tabular}{cc}
\hline Ranking & Distance to and main roads \\
\hline 0 & $0 \mathrm{~m}-500 \mathrm{~m}$ \\
3 & $500 \mathrm{~m}-1000 \mathrm{~m}$ \\
2 & $1000 \mathrm{~m}-2000 \mathrm{~m}$ \\
1 & $>2000 \mathrm{~m}$ \\
\hline
\end{tabular}

Table 8. Classes produced for the railways according to the suitability for landfill [42].

\begin{tabular}{cc}
\hline Ranking & Distance to railways \\
\hline 0 & $0 \mathrm{~m}-500 \mathrm{~m}$ \\
1 & $>500 \mathrm{~m}$ \\
\hline
\end{tabular}

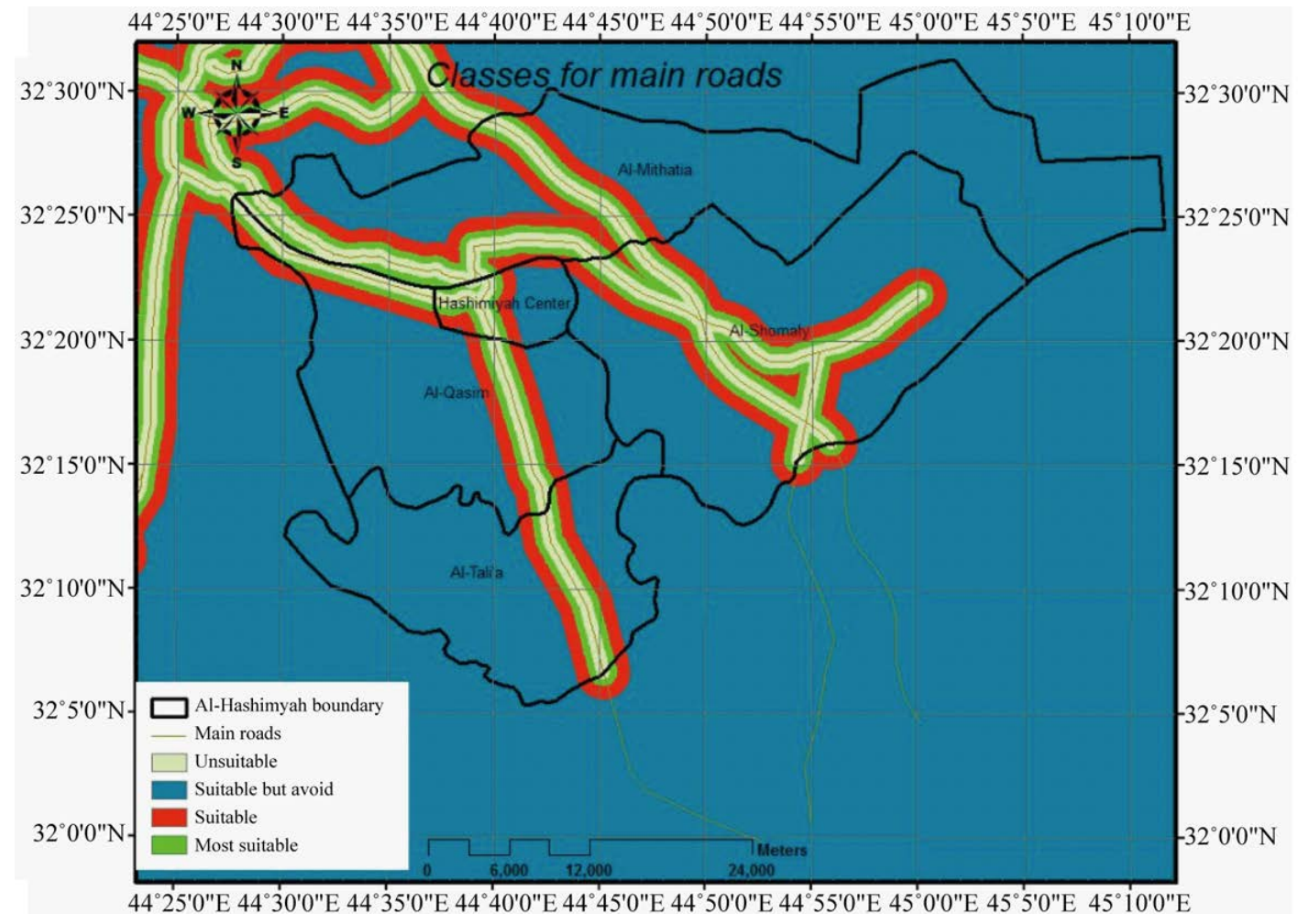

Figure 6. Classes for main roads (source of data from [43]).

and 0 respectively. Then, the vector map prepared was converted to a raster map shown in Figure 7.

\section{4) Airports}

There are different values related to the safe distances from airports like $3.000 \mathrm{~m}$ [46] or $3.048 \mathrm{~m}$ [47]. As stated by Allen, et al. [45] a distance of 10 to $13 \mathrm{~km}$ from flight path should be considered as a buffer zone. By considering these suggested values, the safe distance from airport was determined as $3000 \mathrm{~m}$. This layer was classified as suitable or unsuitable for a landfill site by assigning values 1 and 0 respectively (Table 9 and Figure 8). To finalize the map for the analysis, the vector map was converted to raster map.

\section{5) Surface Water}

The necessary buffer zone for swamp areas was determined as $250 \mathrm{~m}$ [42]. The layer of wetlands was classified as suitable or unsuitable by assigning values 1 and 0 , respectively (Table 10). The buffer zones were created and the study area was divided into two classes in the GIS environment. Then, the vector map prepared 


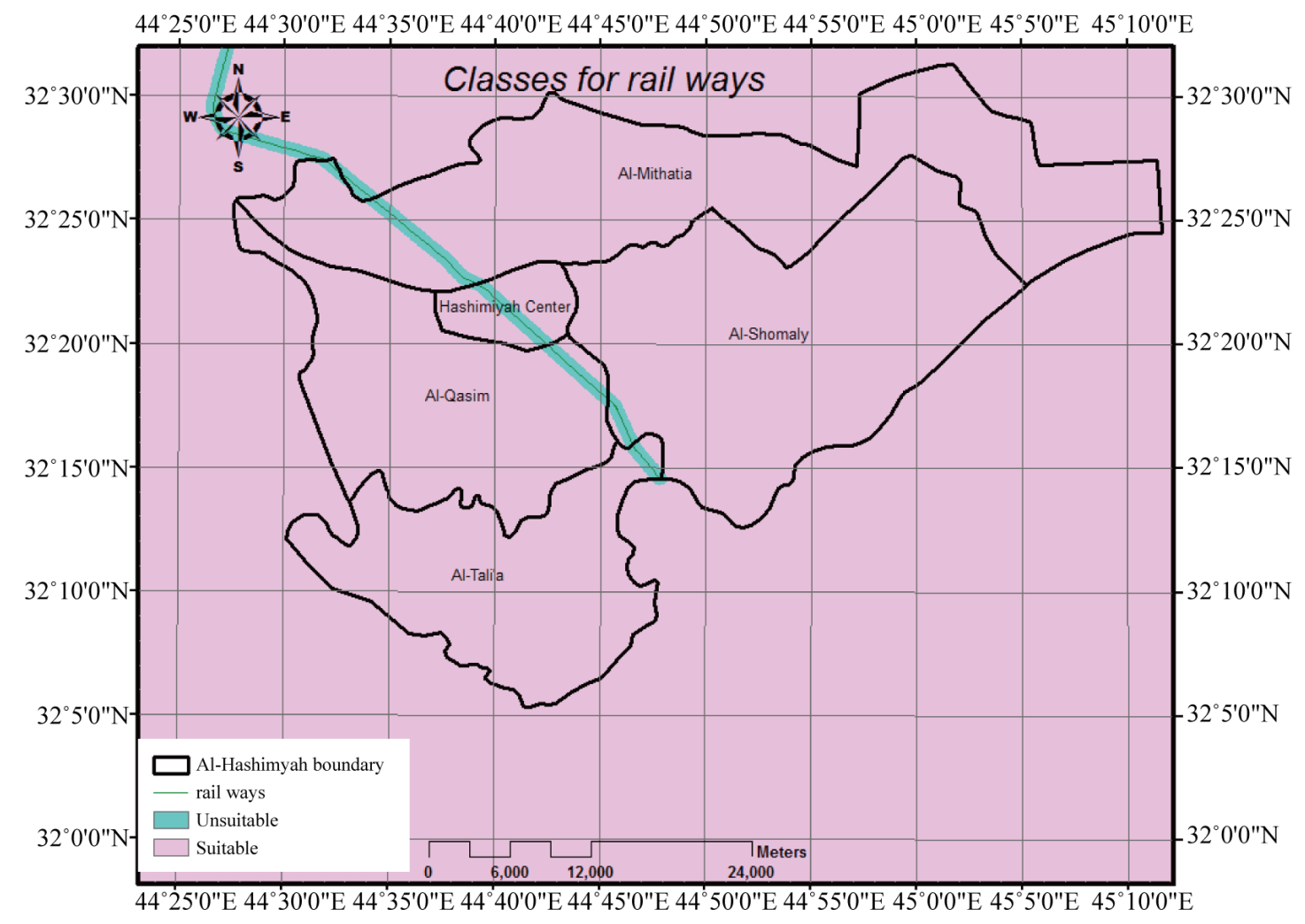

Figure 7. Classes for rail ways (source of data from [43]).

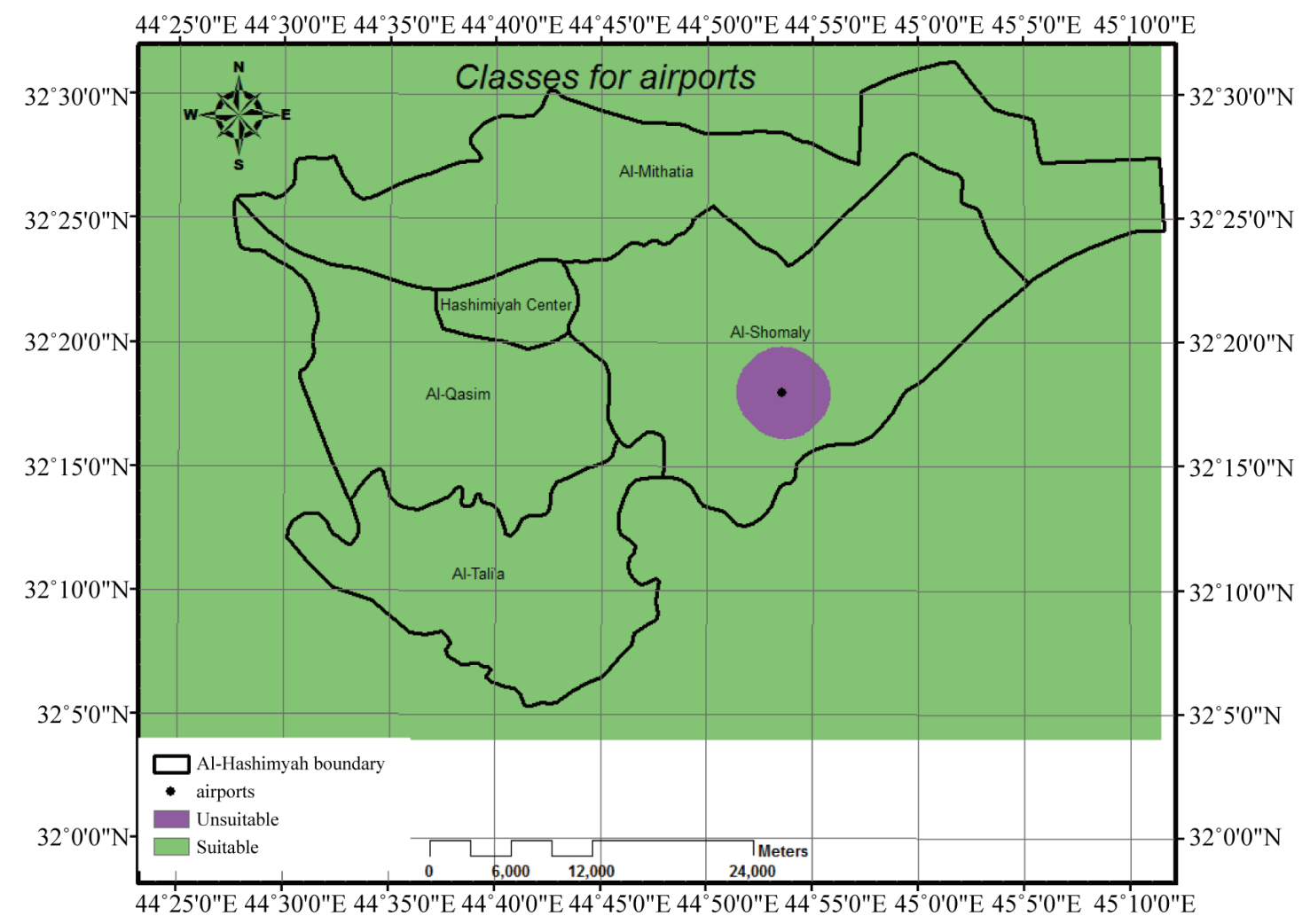

Figure 8. Classes for airports (source of data from [43]). 
Table 9. Classes produced for airport according to the suitability for landfill [42].

\begin{tabular}{cc}
\hline Ranking & Distance to airport \\
\hline 0 & $0 \mathrm{~m}-3000 \mathrm{~m}$ \\
1 & $>3000 \mathrm{~m}$ \\
\hline
\end{tabular}

Table 10. Classes produced for surface water according to the suitability for landfill [42].

\begin{tabular}{cc}
\hline Ranking & Distance to surface water \\
\hline 0 & $0 \mathrm{~m}-250 \mathrm{~m}$ \\
1 & $>250 \mathrm{~m}$ \\
\hline
\end{tabular}

was converted to a raster map shown in Figure 9 .

\section{6) Pipelines}

Pipelines of Babylon that were considered were those for water and Waste Water Treatment Plants passing through the study area. The necessary buffer zone for them was determined as $250 \mathrm{~m}$ on both sides [42]. The pipeline layer was classified as suitable or unsuitable for a landfill site by assigning values 1 and 0 , respectively (Table 11). After the creation of buffer zones, the vector map prepared was converted to a raster map shown in Figure 10 to be used as an input map in the analysis.

\section{7) Power Lines}

The necessary buffer zone distance should be considered so that it does not disturb the infrastructures and all high voltage power lines. It should have a buffer of $30 \mathrm{~m}$ on both sides of the site [40]. The buffer zones were created in the GIS environment. The layer of power lines was classified as suitable or unsuitable for a landfill site by assigning values 1 and 0 respectively (Table 12). Then, the vector map was prepared and converted to a raster map as shown in Figure 11.

According to Alsharify [48], the texture of Babylon soil analyzed was almost silt clay loam. Table 13 shows adopted test results of texture of Babylon soil [48].

Comparison of this table with Table 14 [49], in addition to the map (Figure 12), shows that Babylon city soils and its environs are suitable for landfill construction without specific variation on its texture which should be taken in the digital maps analysis (Figure 13). The raster map was used as an input map in the analysis.

\section{8) Streams}

The necessary buffer zone for the stream sewer determined as $300 \mathrm{~m}$ on both sides [42]. The surface water layer was classified as suitable or unsuitable for a landfill site by assigning values 1 and 0 , respectively (Table 15). After the creation of buffer zones, the vector map was prepared and converted to a raster map as shown in Figure 14.

\section{9) Oil Pipes}

The necessary buffer zone for oil pipes was determined as $75 \mathrm{~m}$ [source/Pipes Lines Company] on both sides. The surface water layer was classified as suitable or unsuitable for a landfill site by assigning values 1 and 0 , respectively (Table 16). After the creation of buffer zones, the vector map was prepared and converted to a raster map shown in Figure 15 [50].

\section{0) Liquid Gas Pipes}

The necessary buffer zone for liquid gas pipes was determined as $300 \mathrm{~m}$ [source/Pipes Lines Company] on both sides. The surface water layer was classified as suitable or unsuitable for a landfill site by assigning values 1 and 0 , respectively (Table 17). After the creation of buffer zones, the vector map was prepared and converted to a raster map shown in Figure 16.

\section{1) Land Use}

In the study area, there are different land uses (see Table 18 and Figure 17). Land use types were grouped and ranked according to their suitability for a landfill site as unsuitable, moderate suitable and suitable for a landfill site by assigning values 0,5 and 10 respectively. The land use vector map was then converted to a raster map Figure 18).

\section{2) Digital Elevation Model}




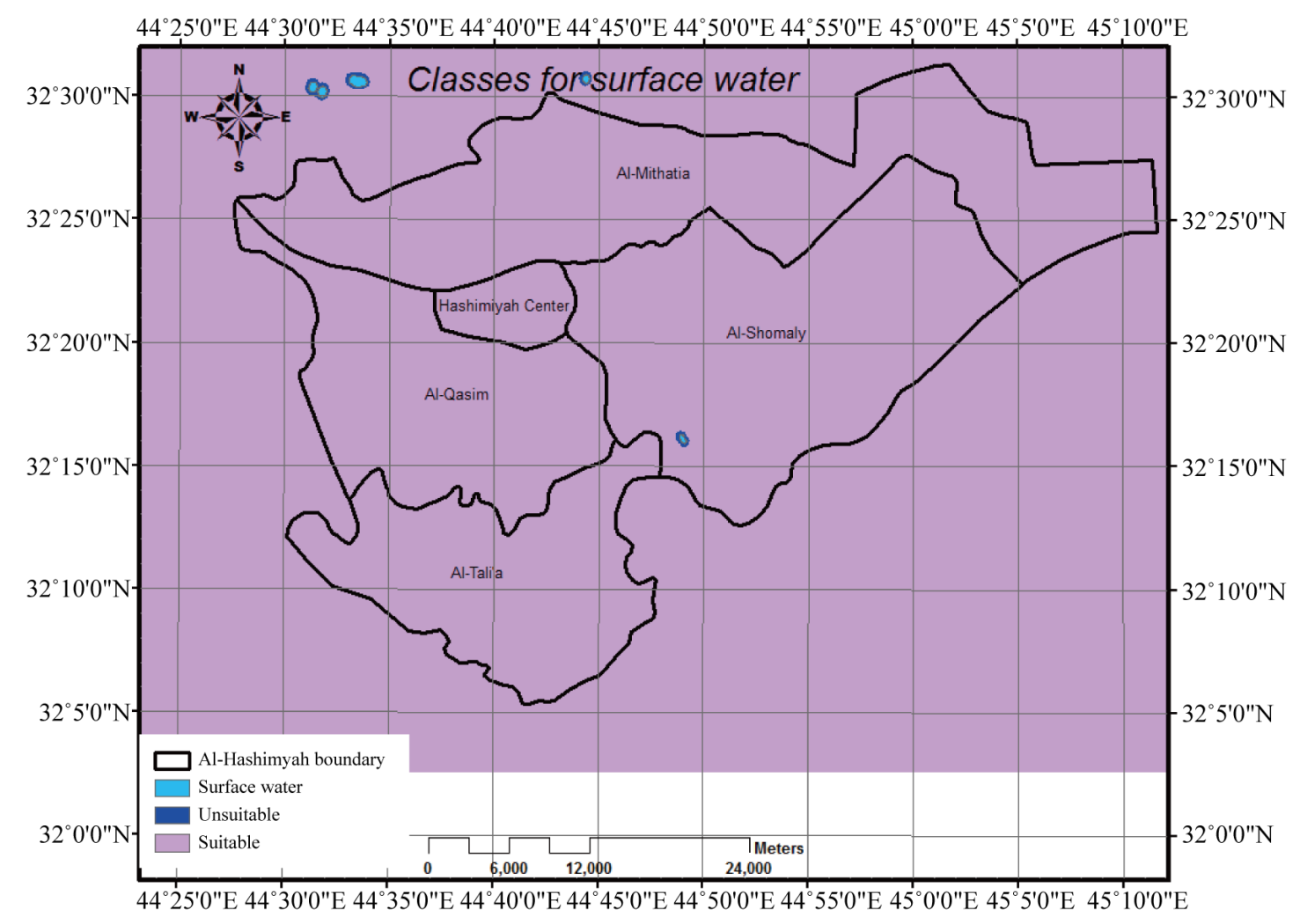

Figure 9. Classes for surface water.

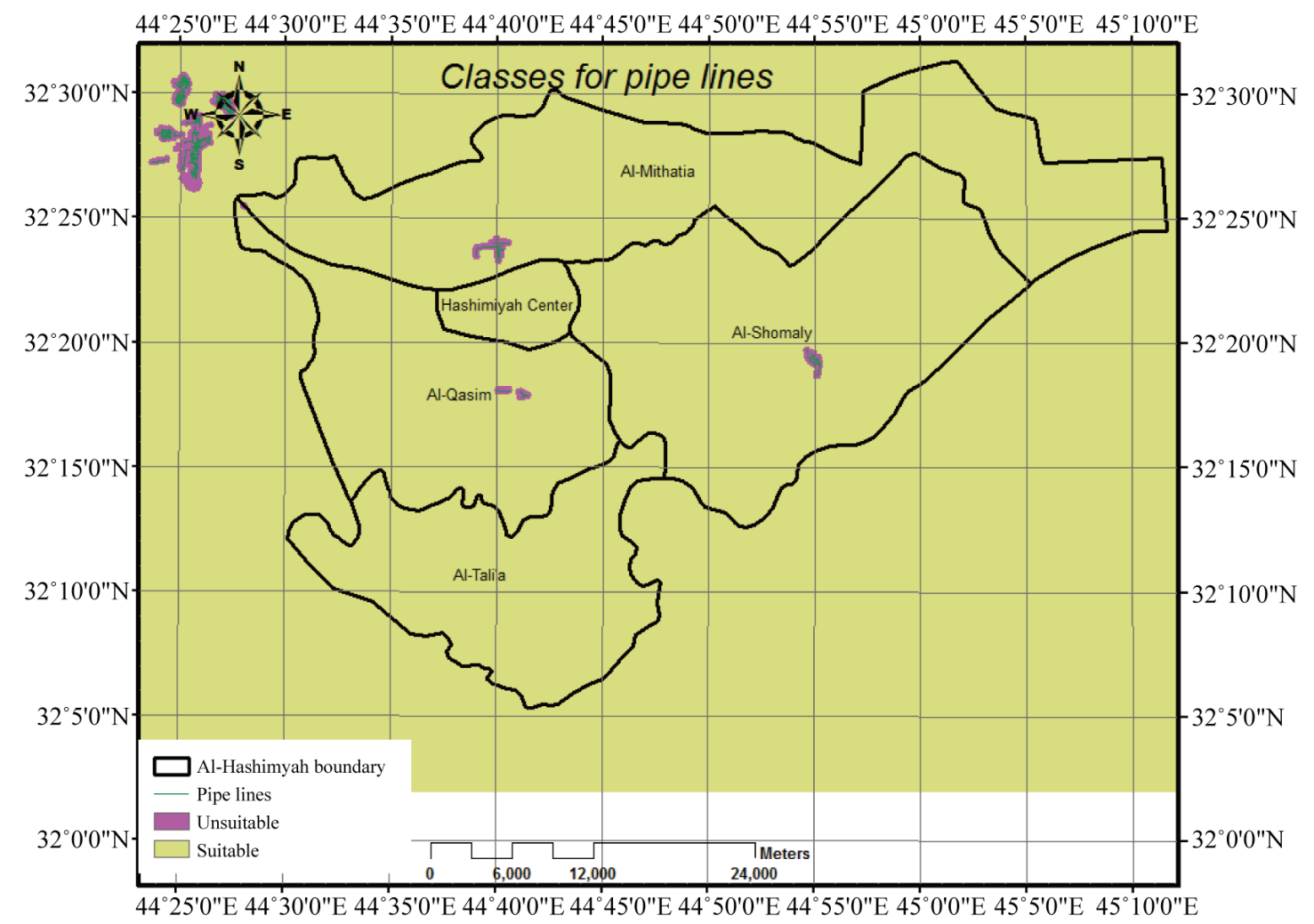

Figure 10. Classes for pipe lines (source of data from [43]). 


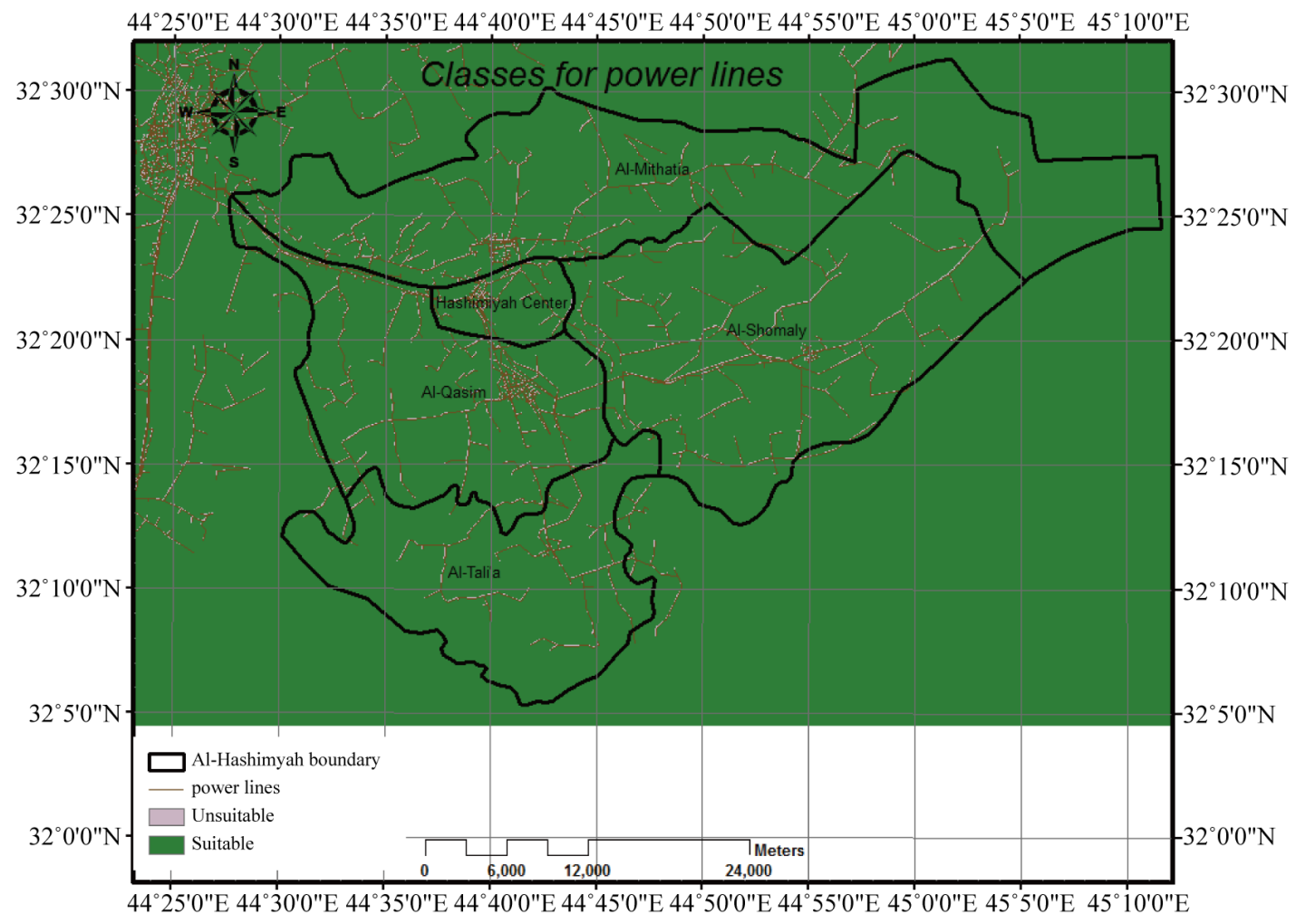

Figure 11. Classes for power lines.

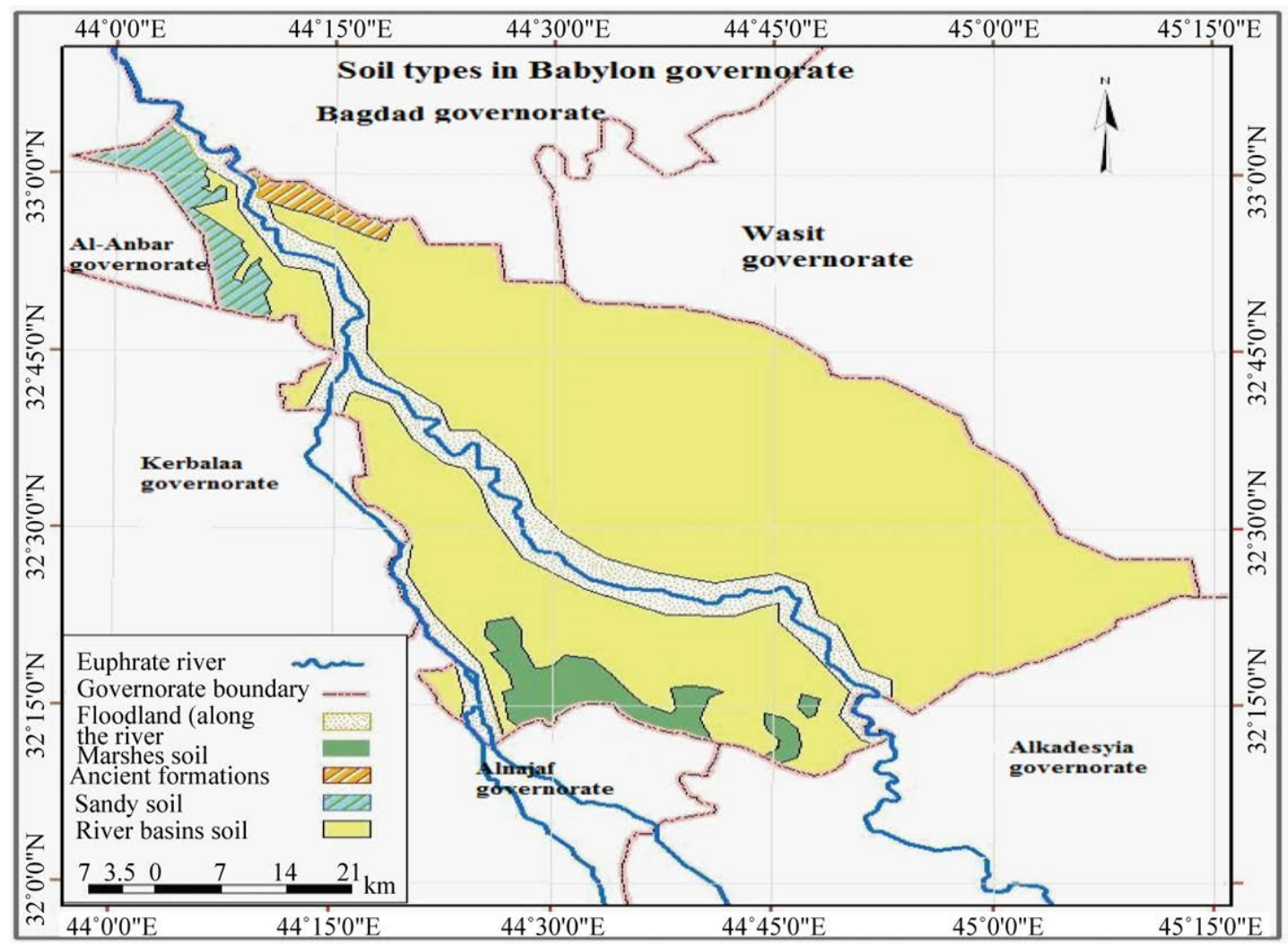

Figure 12. Soil types in Babylon governorate. 


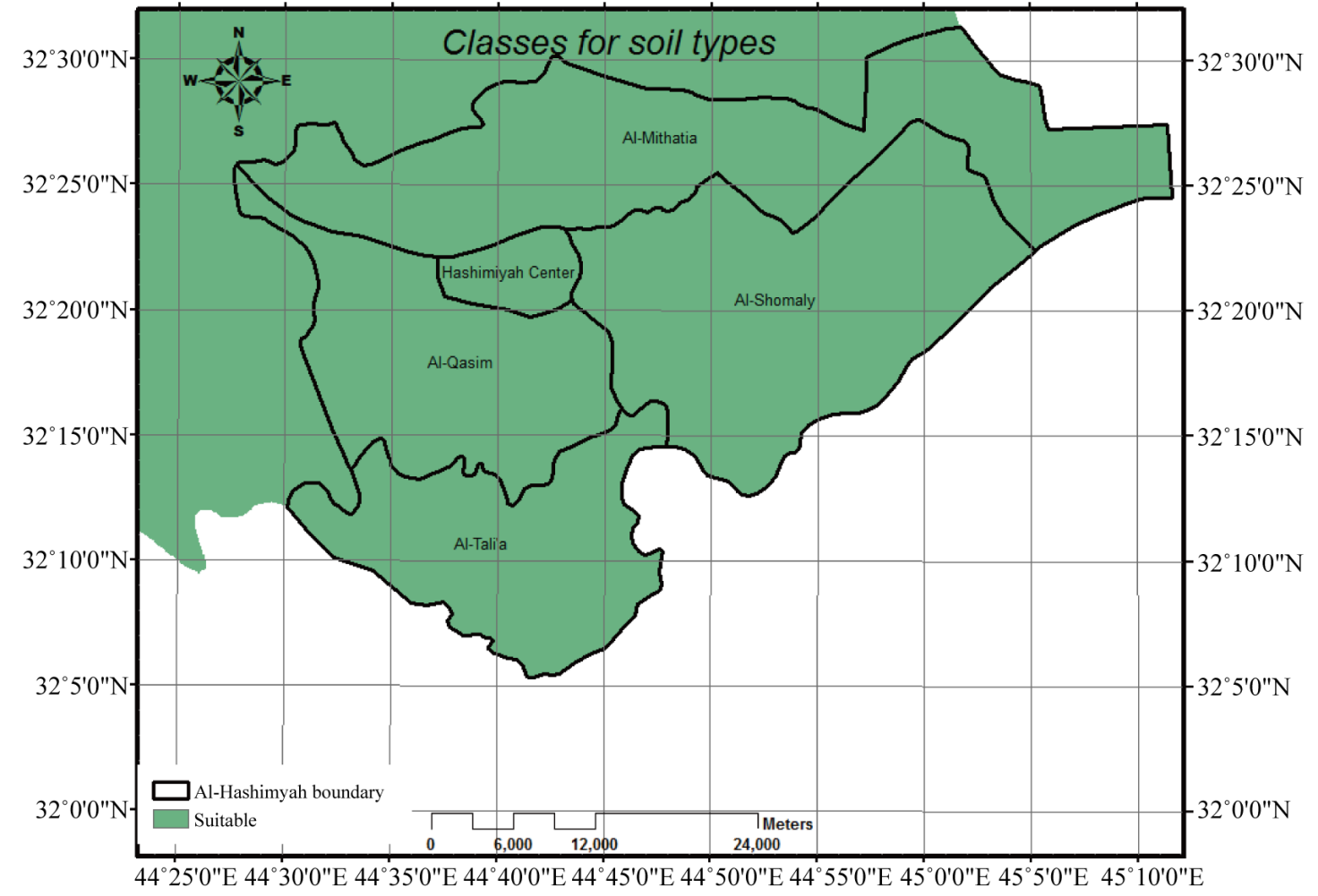

Figure 13. Classes for soil types.

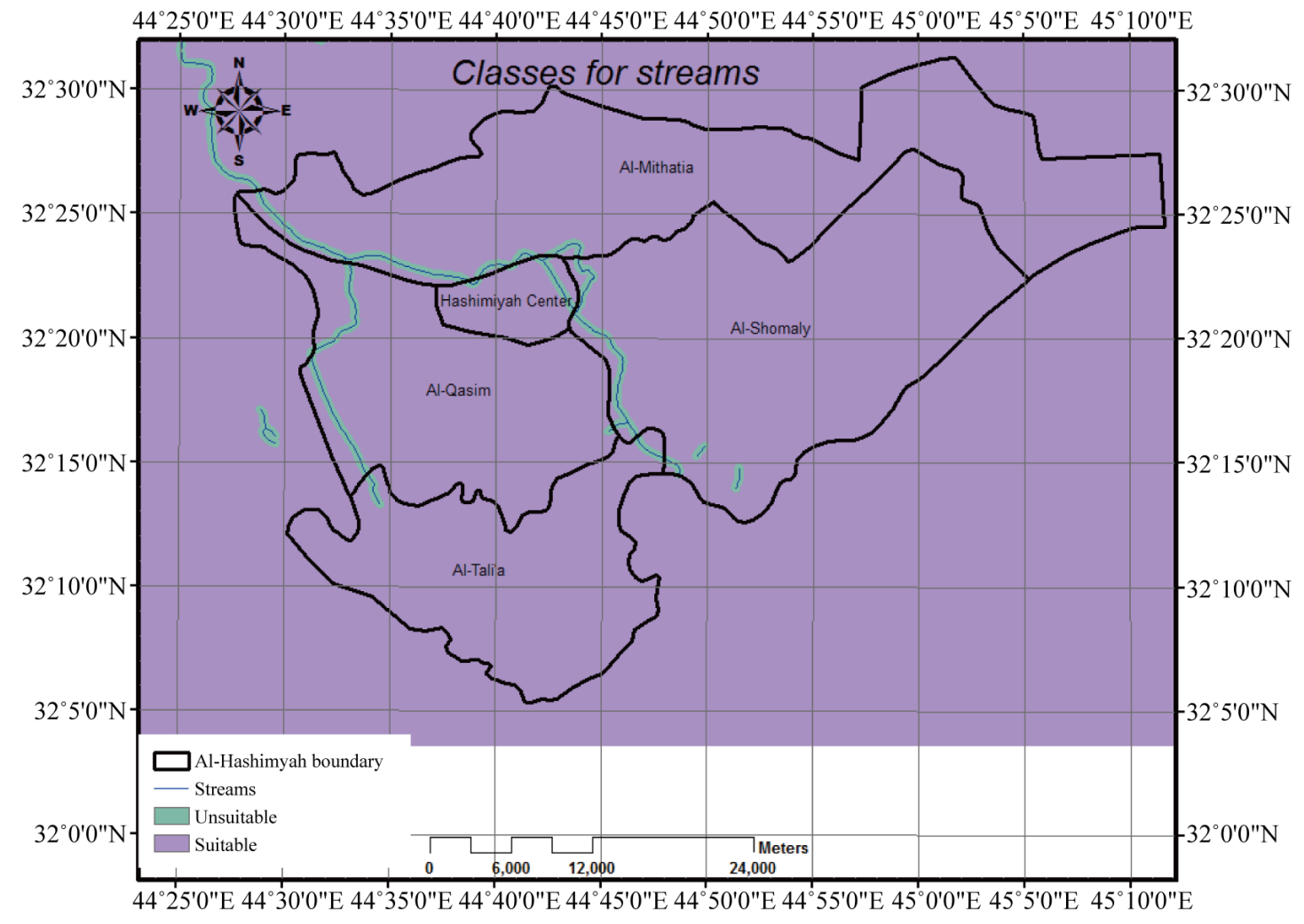

Figure 14. Classes for streams. 


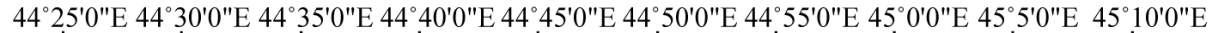

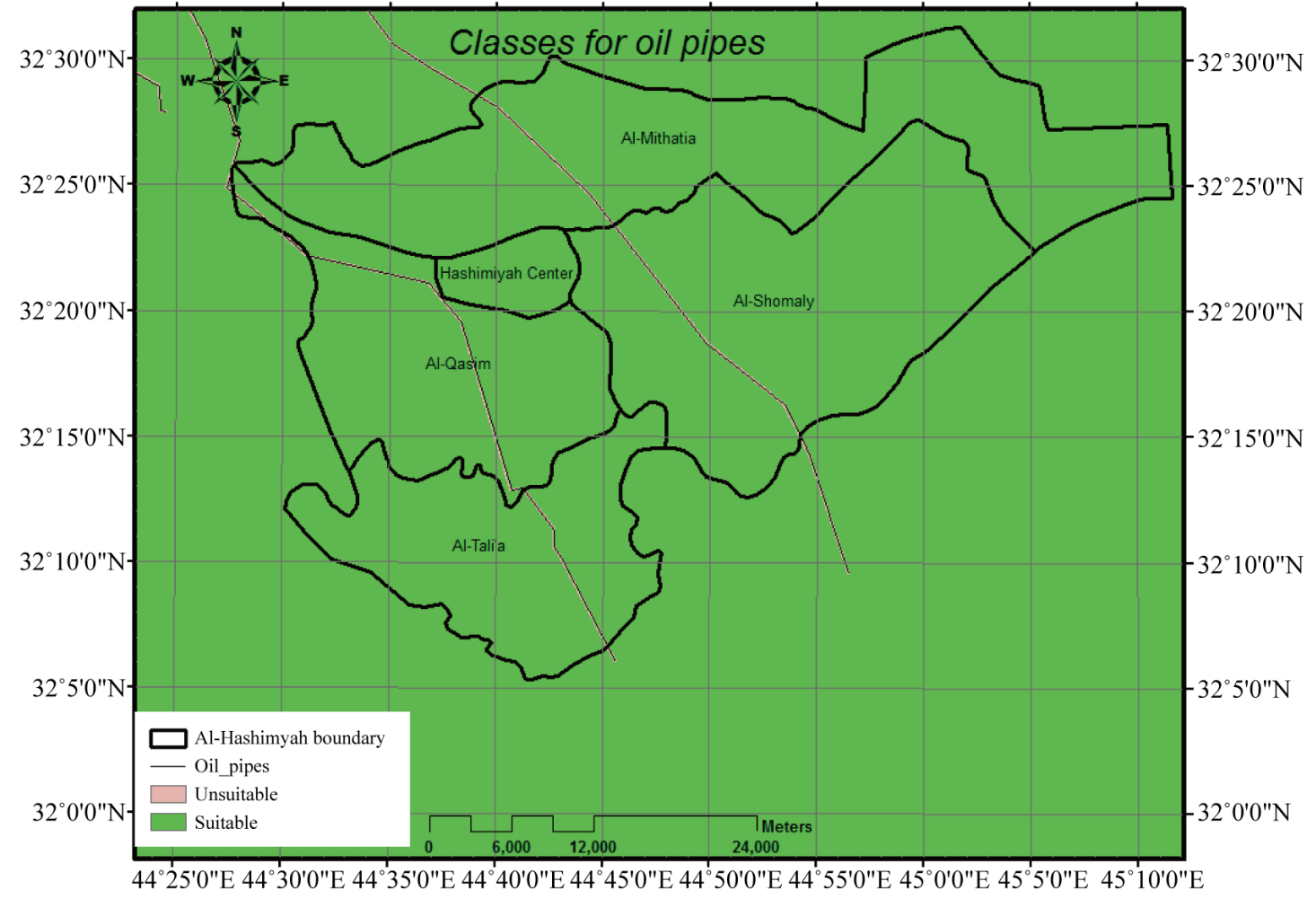

Figure 15. Classes for oil pipes (source of data [50]).

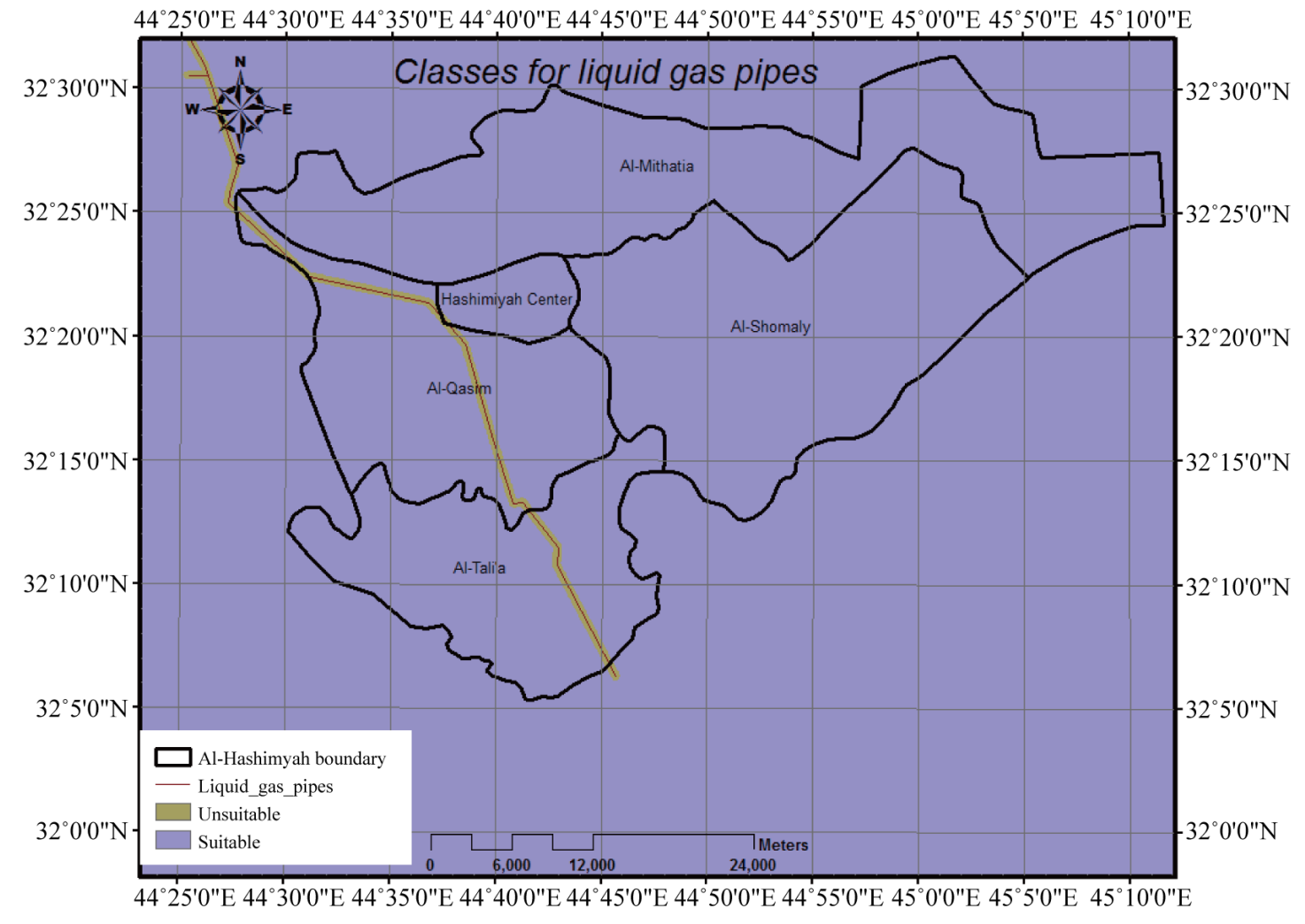

Figure 16. Classes for liquid gas pipes (source of data [50]). 


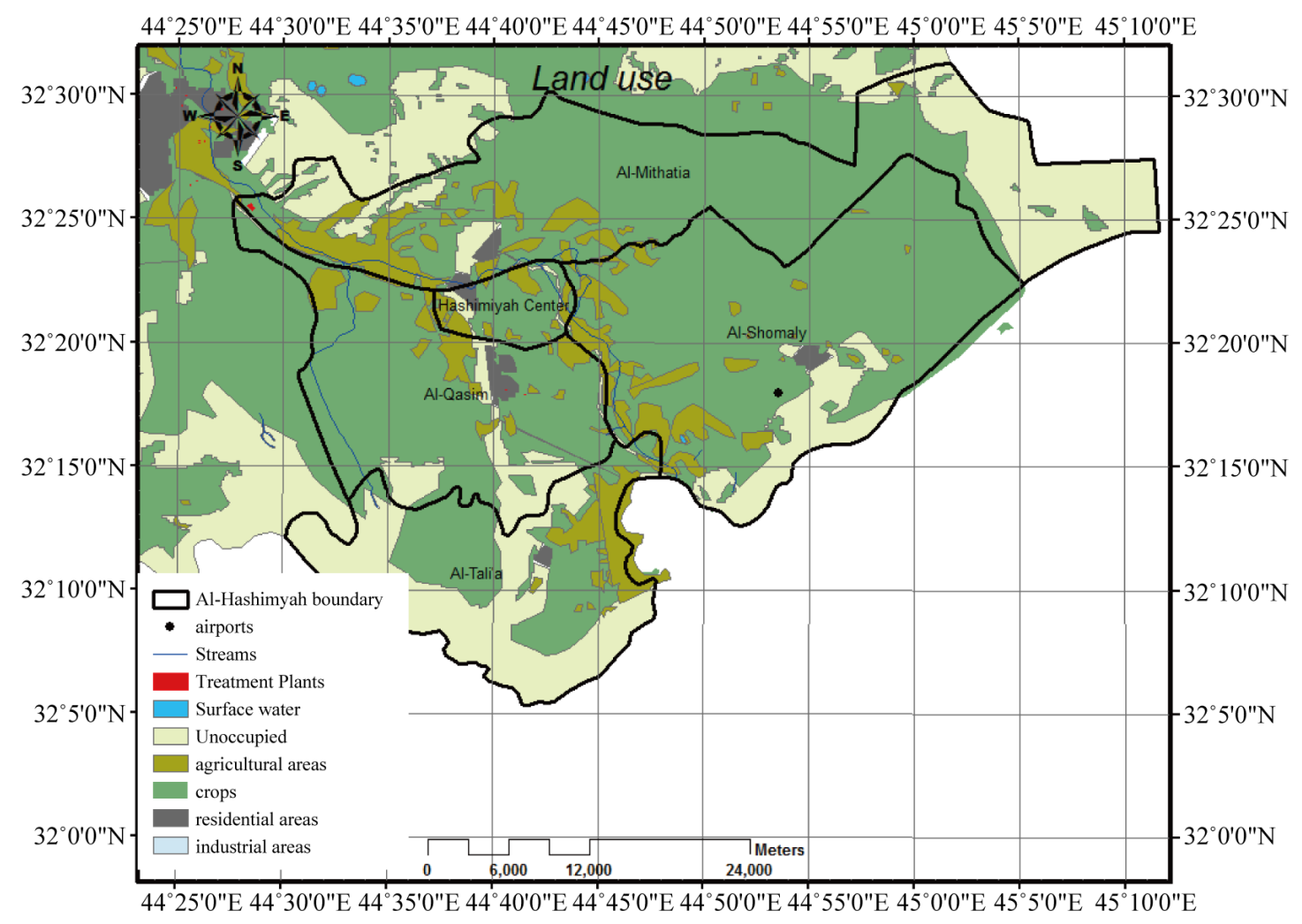

Figure 17. Land use (source of data [43]).

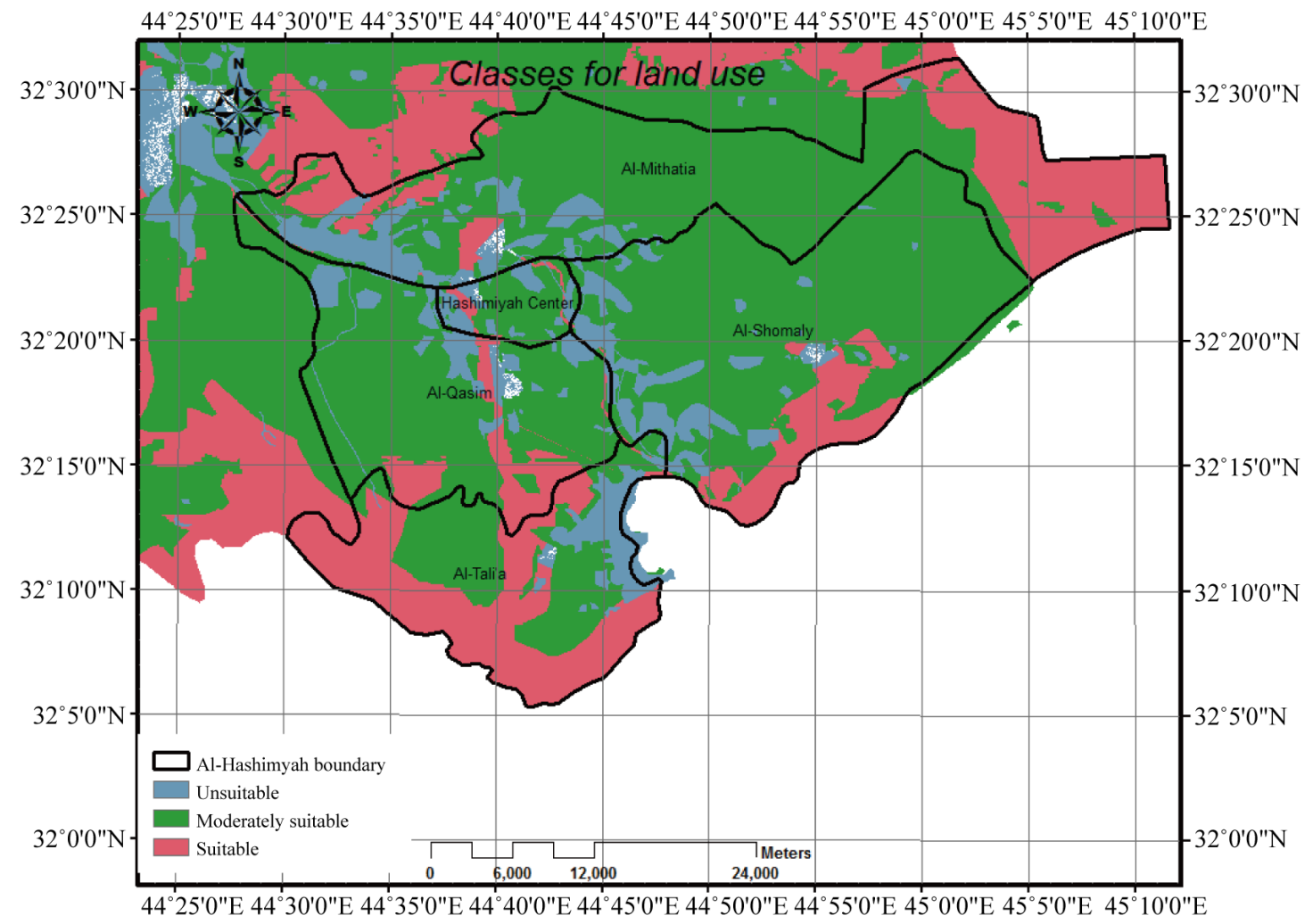

Figure 18. Classes for land use. 
Table 11. Classes produced for pipelines according to the suitability for landfill [42].

\begin{tabular}{cc}
\hline Ranking & Distance to pipelines \\
\hline 0 & $0 \mathrm{~m}-250 \mathrm{~m}$ \\
1 & $>250 \mathrm{~m}$ \\
\hline
\end{tabular}

Table 12. Classes produced for high voltage power lines according to suitability [42].

\begin{tabular}{cc}
\hline Ranking & Distance to power lines \\
\hline 0 & $0 \mathrm{~m}-30 \mathrm{~m}$ \\
1 & $>30 \mathrm{~m}$ \\
\hline
\end{tabular}

Table 13. Adopted test results of texture of Babylon soil [48].

\begin{tabular}{|c|c|c|c|c|c|}
\hline Texture type & Clay gm/Kg & Alluvial gm/Kg & Sand $\mathrm{gm} / \mathrm{Kg}$ & Sample & Depth $(\mathrm{cm})$ \\
\hline \multirow{5}{*}{ Silt clay loam } & 383 & 466 & 151.04 & 1 & \multirow{5}{*}{$0-15$} \\
\hline & 365 & 489 & 146.00 & 2 & \\
\hline & 370 & 470.02 & 159.98 & 3 & \\
\hline & 373 & 475 & 152.34 & Av & \\
\hline & 372.66 & 461.35 & 166.65 & 1 & \\
\hline \multirow{5}{*}{ Silt clay loam } & 390 & 441 & 169.00 & 2 & \multirow{2}{*}{$15-20$} \\
\hline & 358 & 479 & 163.00 & 3 & \\
\hline & 373.33 & 460.45 & 166.22 & Av & \multirow{6}{*}{$20-25$} \\
\hline & 380 & 450 & 170.00 & 1 & \\
\hline & 360 & 470 & 170.00 & 2 & \\
\hline \multirow{3}{*}{ Silt clay loam } & 370 & 450 & 180.00 & 3 & \\
\hline & 370 & 456.66 & 173.33 & Av & \\
\hline & 372 & 464.04 & 163.96 & Tot-Av & \\
\hline
\end{tabular}

Table 14. Soil textures and landfill suitability [49].

\begin{tabular}{cc}
\hline Suitability & Soil type \\
\hline Very high & Silt to very fine silty clay \\
High & Clay \\
Moderate & Mixed \\
Low & Sandy \\
Unsuitable & Clean sand/gravel \\
\hline
\end{tabular}

Table 15. Classes produced for streams according to the suitability for landfill [42].

\begin{tabular}{cc}
\hline Ranking & Distance to streams \\
\hline 0 & $0-300 \mathrm{~m}$ \\
1 & $>300 \mathrm{~m}$ \\
\hline
\end{tabular}

Table 16. Classes produced for oil pipes according to the suitability for landfill.

\begin{tabular}{cc}
\hline Ranking & Distance to oil pipes \\
\hline 0 & $0-75 \mathrm{~m}$ \\
1 & $>75 \mathrm{~m}$ \\
\hline
\end{tabular}


Table 17. Classes produced for liquid gas pipes according to the suitability for landfill [50].

\begin{tabular}{cl}
\hline Ranking & \multicolumn{1}{c}{\begin{tabular}{c}
\multicolumn{1}{c}{ Distance to liquid gas pipes } \\
0
\end{tabular}} \\
\hline 1 & \multicolumn{1}{c}{$>300 \mathrm{~m}$} \\
\hline Table 18. Land use types and their rankings. \\
\hline Ranking & Land use type \\
\hline 0 & Residential areas \\
0 & Industrial areas \\
0 & Water \& waste water treatment plant \\
0 & Agricultural areas \\
0 & Streams \\
0 & Surface water \\
0 & Airports \\
5 & Crops \\
10 & Unoccupied land \\
\hline
\end{tabular}

Digital Elevation Model (DEM), also referred to as the Digital Terrain Analysis, is a digital representation of earth's topography in a continuous way [47]. A slope map was generated from DEM. The potential for slope failure was related to the degree or grade of the topography. Slope failure underneath or adjacent to landfills, will result in waste containment failure and release of debris into the surrounding area. Land with slopes greater than $15 \%$ should be considered unsuitable for waste disposal sites [47]. The slope layer was classified as suitable or unsuitable for a landfill site by assigning values 1 and 0, respectively (Table 19 and Figure 19).

\section{3) Overlay analysis}

Output values of the resultant map was prepared using overlay analyses of ArcGIS Spatial Analyst, land suitability of the study area was calculated by LSI. Calculated LSI varied between 0.436 and 4.161 . The very high and very low suitable areas were determined. Pixels with 0.436 (colored red) were considered as very low suitable and were excluded from the alternative candidates' sites to be examined as disposal areas. On the other hand, pixels with values around 4.161 are likely to be more suitable and were colored blue (Figure 20).

\subsubsection{Actual Case Requirement}

\section{1) District (Nahia) Center}

Technically, the distance from the center of a collection route to the landfill should be less than $20-25 \mathrm{~km}$ [39]. Therefore, adopting of $20 \mathrm{~km}$ was used to cover all zigzag roads from centers of each district. The output map produced is given in Figure 21. The suitable land intersected with specific layers of buffer zones around district centers were selected as landfill sites. The output map produced is given in Figure 21. This map shows the landfill sites selected to cover all Al-Hashimyah qadaa municipal solid wastes disposal.

\section{2) Landfill Area}

According to Tchobanoglous [3], the principle methods used for land filling in dry areas can be classified as: 1) Area, 2) Trench, and 3) Depression.

The adopted method in this research was the area method which is more suitable for Babylon environs lands of shallow ground water table depth that is from 3 to $4 \mathrm{~m}$ Available area of the selected landfill, and nahias serve reaches an area of $828,255 \mathrm{~m}^{2}$.

Once the amount of waste generated had been estimated, landfills should be designed in cells with sufficient capacity to receive the cumulative volume of waste generated. The optimal capacity of a landfill site should be not less than 5 years in order to ensure that the major investments required by the landfill are spread over large tonnage of waste.

The cumulative volume of wastes expected to be generated between 2013 and 2017 of selected landfill. The adopted density of the waste in the landfill was $450 \mathrm{~kg} / \mathrm{m}^{3}$. It was not accounted for any reduction in the waste 
Table 19. Classes produced for slope according to the suitability for landfill [47].

\begin{tabular}{cc}
\hline Ranking & Classes for slope \\
\hline 0 & $\leq 15 \%$ \\
1 & $>15 \%$ \\
\hline
\end{tabular}

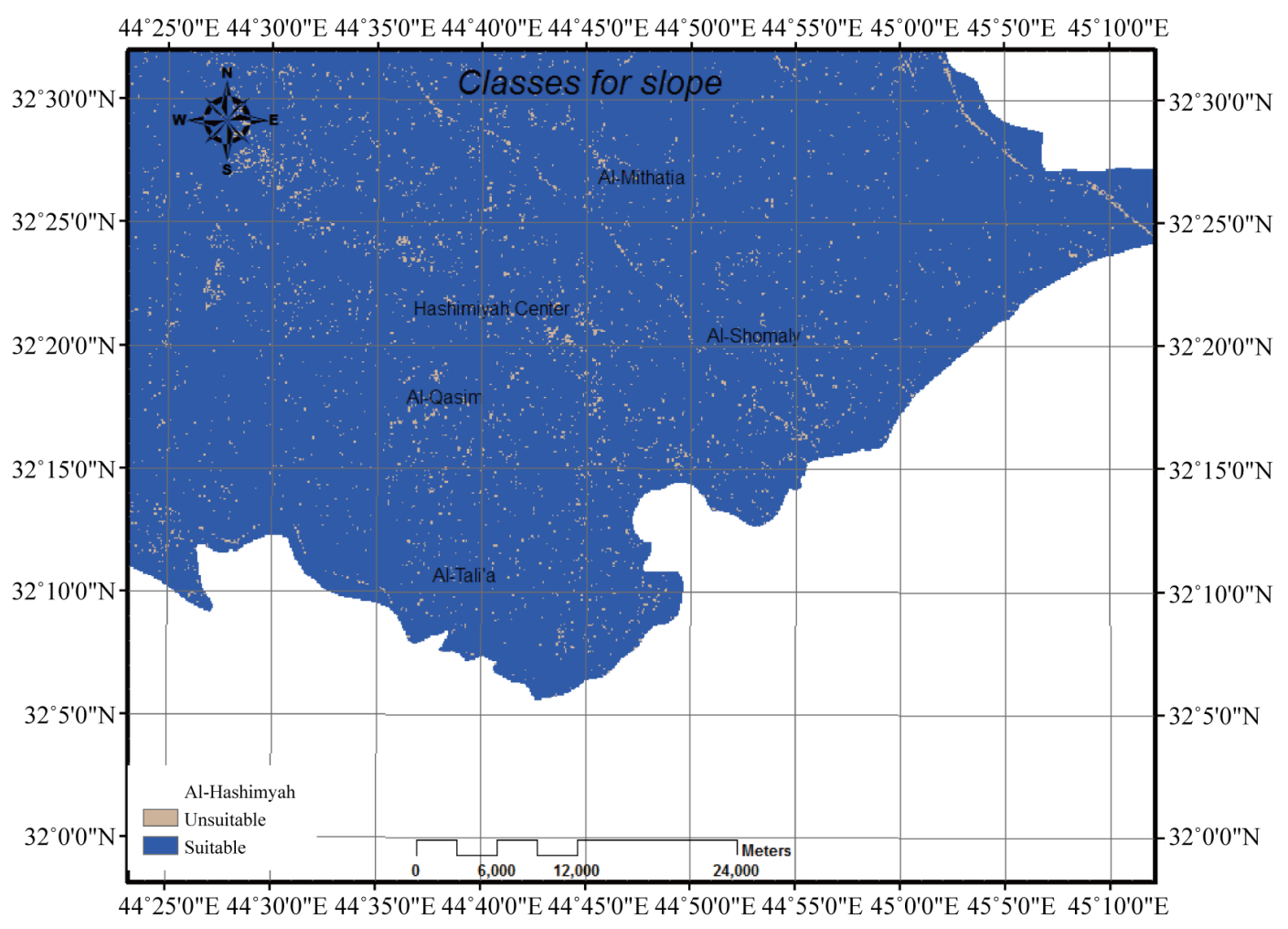

Figure 19. Classes for slope.

going to the landfill through recycling or composting at this stage. Waste in the landfill should be covered daily by a daily cover in order to minimize health, safety and environmental impacts and nuisances. The volume of daily cover in the landfill varies between $10 \%$ and $15 \%$ of the waste volume [42]. Adopting a value of $10 \%$ of the waste volume, the required capacity of the landfill over the next five years can be estimated as $1,006,470 \mathrm{~m}^{3}$.

Wastes are to be unloaded to landfill site and spread in long narrow strips on the surface of land in series of layers in depth of $50 \mathrm{~cm}$. Each layer is to be compacted at the filling progresses during the course of the day until the thickness of the compacted wastes reaches a high of $3 \mathrm{~m}$. The cover material is to be hauled in by earth moving equipment from adjacent land or from borrow pit areas. The width over which the wastes are to be compacted is $6 \mathrm{~m}$ [42]. Required areas of the selected landfill are $335490 \mathrm{~m}^{2}\left(32^{\circ} 19^{\prime} 30^{\prime \prime} \mathrm{N}\right.$ and $\left.44^{\circ} 49^{\prime} 0^{\prime \prime} \mathrm{E}\right)$ in Al-Hashemiaqadaa in Al-Shomalynahia.

It was noticed that the available area $\left(828,255 \mathrm{~m}^{2}\right)$ of selected landfill is quite more than the required areas estimated for 5 years. Figure 22 shows the suggested landfill sites.

\section{3) Field Visits Review}

In order to check the suitability of the area derived from the analysis and the actual case requirement (nahia center and landfill area), field check was performed out to determine the accuracy and suitability of candidate sites. The selected sites were checked on the satellite image 2006. Planning and Agriculture directorates in Babylon governorate checked the suggested sites in case that there are projects within the suggested sites. Due to the fact that there is no accurate documented information available for religious and archeological sites, physical field visits were performed. All the neither sites were surveyed in cooperation with the Al-Shomaly agriculture division. It was found that the suggested landfill sites are suitable and does not affect the agricultural activities 


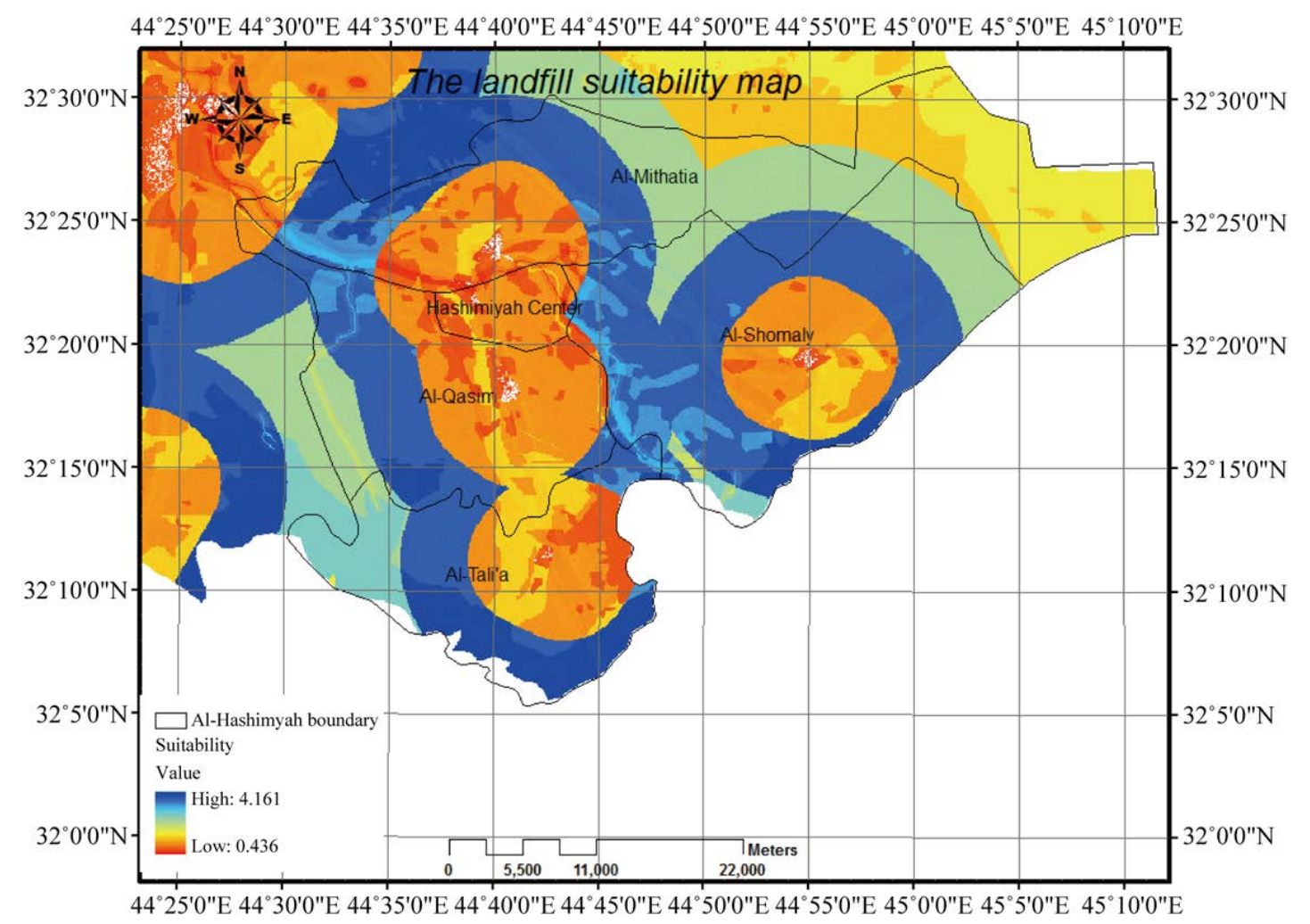

Figure 20. Output map produced with its suitability index.

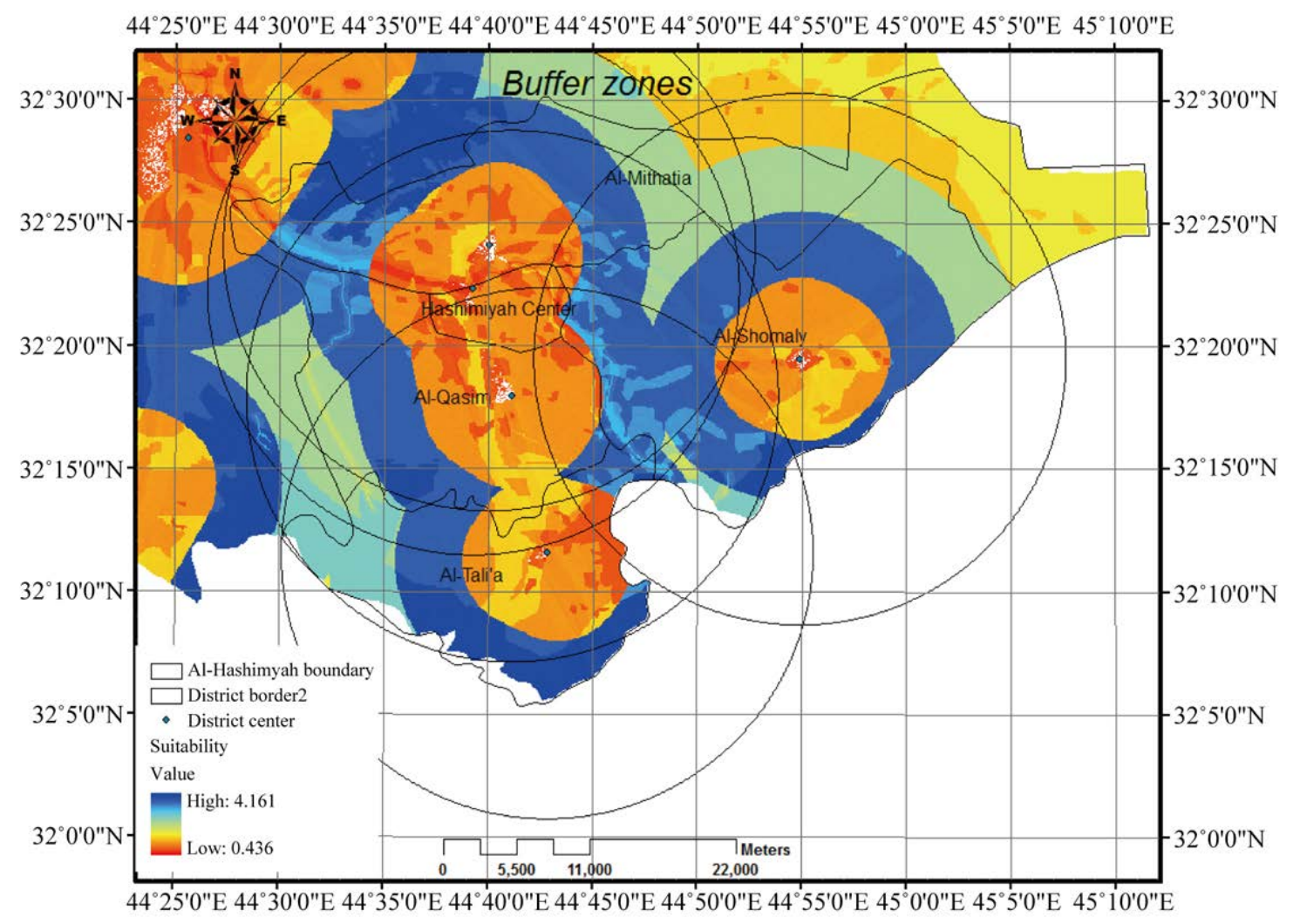

Figure 21. Buffer zones. 


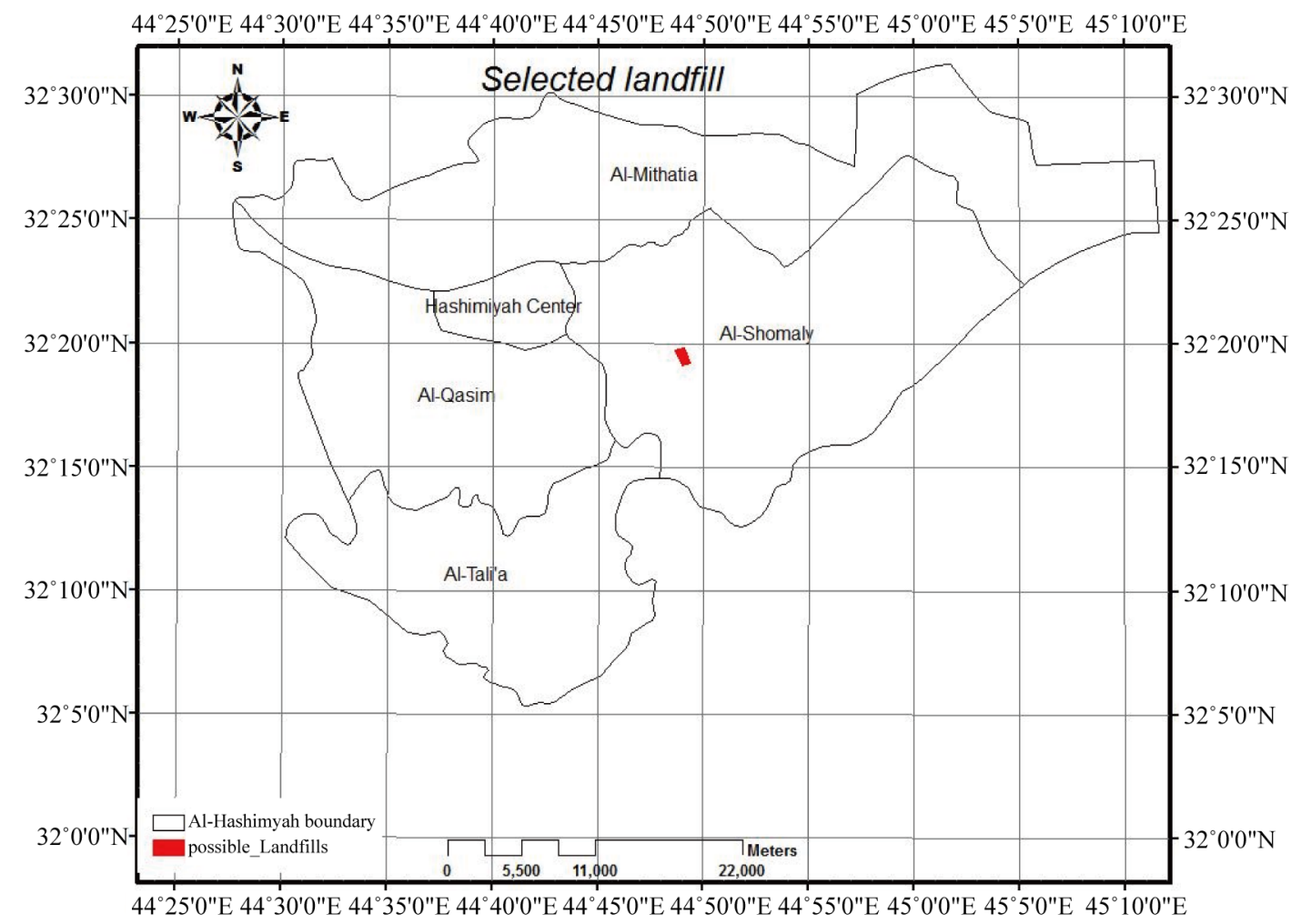

Figure 22. The selected landfill.

nor religious or archeological sites.

\section{Conclusions}

The results of using GIS and Multicriteria Decision Analysis for Landfill Site Selection for Al-Hashimyah Qadaa using 14 variables showed that total landfilling areas that are required to cover cumulative MSW volume generated in 5 years are 3,034,035 $\mathrm{m}^{2}$ while the suitable selected areas determined by this study were 3,156,778 $\mathrm{m}^{2}$. Therefore, the selected landfill sites will be available for more than 5 years as an estimated operation time.

The analysis indicated that about $878 \mathrm{~km}^{2}$ at Al-Hashimyahqadaa, had suitability index between 0.436 and 4.161. The very high and very low suitable areas were determined. Pixels with 0.436 (colored red) are considered as very low suitable and were excluded as possible candidate sites. On the other hand, pixels with values around 4.161 were considered to be more suitable and are colored blue.

The presented approach is easy to understand and it can illustrate which areas are better or less suitable for landfill site selection. The criteria used in this study are not fixed factors since it can vary from area to area and these criteria can be changed accordingly in the analysis process. Apart from that, the presented methodology can explain clearly and directly the analysis and results in an easily understandable format. As a result, when the approach and results of the suitability map could be clearly understood, it can assist in getting full support especially from the public.

\section{References}

[1] Al-Ansari, N.A. (2013) Locating Landfills in Arid Environment. Journal of Earth Sciences and Geotechnical Engineering, 3, 11-24.

[2] Allende, R. (2009) Waste History in the Gambia. MSc Thesis, University of the Gambia, Sere Kunda.

[3] Tchobanoglous, G. and Kreith, F. (2002) Handbook of Solid Waste Management. McGraw-Hill, New York.

[4] Kao, J.J. and Lin, H. (1996) Multifactor Spatial Analysis for Landfill Siting. Journal of Environmental Engineering, 122, 902-908. 
[5] Al-Ansari, N.A., Pusch, R. and Knutson, S. (2013) Suggested Landfill Sites for Hazardous Waste in Iraq. Journal of Natural Science, 5, 463-477. http://dx.doi.org/10.4236/ns.2013.54060

[6] Al-Ansari, N.A., Al-Hanbali, A. and Knutsson, S. (2012) Locating Solid Waste Landfills in Mafraq City, Jordan. Journal of Advance Science and Engineering Research, 2, 40-51.

[7] Siddiqui, M.Z., Everett, J.W. and Vieux, B.E. (1996) Landfill Siting Using Geographic Information Systems: A Demonstration. Journal of Environmental Engineering, 122, 515-523. http://dx.doi.org/10.1061/(ASCE)0733-9372(1996)122:6(515)

[8] Halvadakis, C.P. (1993) Municipal Solid Waste Landfill Siting in Greece-The Case of the Greater Hania Region, Greece. Ekistics, 358, 45-52.

[9] Bonham-Carter, G.F. (1994) Geographic Information Systems for Geoscientists. Pergamon-Elsevier Science Ltd, Oxford.

[10] Ehleret, G., Cowen, D. and Mackey, H. (1995) Design and Implementation of a Spatial Decision Support System for Site Selection. Proceedings of ESRI International User Conference, Palm Springs, 22-26 May, 100.

[11] Balis, M., Mandylas, C., Kontos, T., Akriotis, D. and Halvadakis, C.P. (1998) Investigation of Suitable Areas for the Construction of Sanitary Landfill in Lemnos. Technical Report, Part I, University of the Aegean, Department of Environmental Studies, Waste Management Laboratory/Region of the North Aegean, Mytilene, Lesvos.

[12] Dorhofer, G. and Siebert, H. (1998) The Search for Landfill Sites-Requirements and Implementation in Lower Saxony, Germany. Environmental Geology, 35, 55-65. http://dx.doi.org/10.1007/s002540050292

[13] Yagoub, M. and Buyong, T. (1998) GIS Applications for Dumping Site Selection. Proceedings of the ESRI International User Conference, San Diego, 27-31 July, 107.

[14] Herzog, M. (1999) Suitability Analysis Decision Support System for Landfill Siting and Other Purposes. In: Herzog, M., Ed., Proceedings of the ESRI International User Conference, San Diego.

[15] Lukasheh, A.F., Droste, R.L. and Warith, M.A. (2001) Review of Expert System (ES), Geographical Information System (GIS), Decision Support System (DSS) and Their Application in Landfill Design and Management. Waste Management and Research, 15, 4.

[16] Kontos, T.D., Komillis, D.P. and Halvadakis, C.P. (2003) Siting MSW Landfills in Lesvos Island with a GIS Based Methodology. Waste Management and Research, 21, 262-277. http://dx.doi.org/10.1177/0734242X0302100310

[17] Kontos, T.D., Komilis, D.P. and Halvadakis, C.P. (2005) Siting MSW Landfills with Spatial Multiple Criteria Analysis Methodology. Waste Management, 25, 818-832. http://dx.doi.org/10.1016/j.wasman.2005.04.002

[18] Simşek, C., Kincal, C. and Gündüz, O. (2005) A Solid Waste Disposal Site Selection Procedure Based on Groundwater Vulnerability Mapping. Environmental Geology, 49, 620-633.http://dx.doi.org/10.1007/s00254-005-0111-2

[19] Şener, B., Süzen, M.L. and Doyuran, V. (2006) Landfill Site Selection by Using Geographic Information Systems. Environmental Geology, 49, 376-388. http://dx.doi.org/10.1007/s00254-005-0075-2

[20] Banar, M., Köse, B.M., Özkan, A. and Acar, I.P. (2006) Choosing a Municipal Landfill Site by Analytic Network Process. Environmental Geology, 52, 747-751. http://dx.doi.org/10.1007/s00254-006-0512-X

[21] Gemitzi, A., Petalas, C., Tsihrintzis, V.A. and Pisinaras, V. (2006) Assessment of Groundwater Vulnerability to Pollution: A Combination of GIS, Fuzzy Logic and Decision Making Techniques. Environmental Geology, 49, 653-673. http://dx.doi.org/10.1007/s00254-005-0104-1

[22] Mutlutürk, M. and Karagüzel, R. (2007) The Landfill Area Quality (LAQ) Classification Approach and Its Application in Isparta, Turkey. Environmental and Engineering Geoscience, 13, 229-240. http://dx.doi.org/10.2113/gseegeosci.13.3.229

[23] Nas, B., Cay, T., Iscan, F. and Berktay, A. (2008) Selection of MSW Landfill Site for Konya, Turkey Using GIS and Multi-Criteria Evaluation. Environmental Monitoring and Assessment, 160, 491-500. http://dx.doi.org/10.1007/s10661-008-0713-8

[24] Minor, D. and Jacobs, T. (1994) Optimal Land Allocation for Solid and Hazardous Waste Landfill Siting. Journal of Environmental Engineering, 120, 1095-1108. http://dx.doi.org/10.1061/(ASCE)0733-9372(1994)120:5(1095)

[25] Lin, H. and Kao, J.J. (1999) Enhanced Spatial Model for Landfill Siting Analysis. Journal of Environmental Engineering, 125, 845-851. http://dx.doi.org/10.1061/(ASCE)0733-9372(1999)125:9(845)

[26] Allen, A., Brito, G., Caetano, P., Costa, C., Cummins, V., Donelly, J., Fernades, C., Koukoulas, S., O’Donell, V., Robalo, C. and Vendas, D. (2002) Procedure for the Location of Landfill Sites Using GIS Model. 9th Congress of the International Association of Engineering Geology and the Environment, Durban, 16-20 September, 100.

[27] Kontos, T.D. and Halvadakis, C.P. (2002) Development of a Geographic Information System (GIS) for Land Evaluation for Landfill Siting: The Case of Lemnos Island. 7th National Conference of Hellenic Cartographic Society, Mytilene, 23-26 October. 
[28] Şener, B. (2004) Landfill Site Selection by Using Geographic Information Systems. M.Sc. Thesis, Graduate School of Natural and Applied Sciences of Middle East Technical University, Çankaya.

[29] Din, M.A.M., Jaafar, W.Z.W., Markson Obot, R.M. and Wan, M.A.W.H. (2008) How GIS Can Be a Useful Tool to Deal with Landfill Site Selection. International Symposium on Eoinformatics for Spatial Infrastructure Development in Earth and Allied Science, Hanoi, 4-6 December, 1.

[30] DEAB (Directorate of Environmental Affairs in Babel, Iraq) (2010) Data Collected Form Monthly Reports.

[31] Malczewski, J. (1997) Propagation of Errors in Multicriteria Location Analysis: A Case Study. In: Fandel, G. and Gal, T., Eds., Multiple Criteria Decision Making, Springer, Berlin, 154-155.

[32] Environment Protection Agency (EPA) (2003) Location Criteria Chapter 2 Sub-Part B: In Solid Waste Disposal Facility Criteria: Technical Manual, (USAEPA 530-R-93).

[33] Al-Anbari, M.A., Kadum, N. and Taha, L. (2008) Assessment of the Solid Waste Volume for the Year 2026 in Hilla City and the Required Environmental Management Policies. Kufa University Journal, 10, 109-128.

[34] Al-Baidhani, J.H. and Kadhum, R.H. (2009) The Proposed Design of Bioreactor Landfill of Municipal Solid Waste Disposal in Hilla City. Babylon University, Babylon, 8 p.

[35] Kirkwood, C.W. (1997) Strategic Decision Making: Multiobjective Decision. Analysis with Spreadsheets. Duxbury Press, Belmont.

[36] Eastman, J.R., Jin, W., Kyem, P.K. and Toledano, J. (1993) Raster Procedures for Multicriteria/Multiobjective Decisions. Photogrammetric Engineering and Remote Sensing, 61, 539-547.

[37] Saaty, T.L. (1980) The Analytic Hierarchy Process. McGraw-Hill, New York.

[38] Jasim, H.K. (2012) Using Environmental Information Database to Select Sanitary Landfills in Babylon Governorate. M.Sc. Thesis, Building and Construction Engineering Department, the University of Babylon, Babylon, 103.

[39] Allen, A.R. (2002) Attenuation: A Cost Effective Landfill Strategy for Developing Countries. Proceedings of 9th Congress of the International Association for Engineering Geology and the Environment, Durban, 16-20 September.

[40] Cantwell, R. (1999) Putting Data to Work-GIS and Site Selection Studies for Waste Management Facilities: Eurogise 1999.

[41] World Bank (2004) Sanitary Landfill Siting and Design Guidance. Guidance Published in May 1996 by the World Bank as an Urban Infrastructure Note updated November, Washington.

[42] Alnakeeb, A.N. (2007) Baghdad Solid Waste Study and Landfill Site Selection Using GIS Technique. Ph.D. Thesis, Building and Construction Engineering Department, University of Technology, Iraq.

[43] (2012) Babylon Sewer Directorate, Iraq.

[44] Leao, S., Bishop, I. and Evans, D. (2003) Spatial-Temporal Model for Demand and Allocation of Waste Landfills in Growing Urban Regions. Computers, Environment and Urban System, 28, 353-385.

[45] Allen, A., Brito, G., Caetano, P., Costa, C., Cummins, V., Donnelly, J., Fernandes, C., Koukoulas, S., O’Donnell, V., Robalo, C. and Vendas, D. (2001) Final Project Report. The Development of a GIS Model for the Location of Landfill Sites in Ireland and Portugal. Coastal Resources Centre, University College Cork, Cork.

[46] Chalkias, C.N. and Stournaras, G. (1997) GIS Application for the Selection of Sanitary Waste Disposal Landfills and Quarry Sites in Major Sparti Area, Greece. In: Marinos, K. and Tsiambaos, S., Eds., Engineering Geology and the Environment.

[47] Bagchi, A. (1994) Design, Construction and Monitoring of Landfills. 2nd Edition, John Wiley \& Sons, Inc., New York.

[48] Alsharify, S.K.A. (2009) Effect of Two Types of Plows with Different Depths and Quicken in the Performance of the Almiknyh Unit and Some Physical Characteristics of the Soil. Journal of Babylon University, Pure and Applied Science, 1, 17.

[49] Oweis, I. and Khera, R. (1998) Geotechnology of Waste Management. 2nd Edition, PWS Publishing, Boston.

[50] (2012) Pipes Lines Company, Babylon, Iraq. 